\title{
A Prototype BEA/BLS Industry-Level Production Account for the United States
}

\author{
Susan Fleck* \\ Steven Rosenthal* \\ Matthew Russell** \\ Erich H. Strassner** \\ Lisa Usher*
}

Final version: November, 2012

Presented at

$2^{\text {nd }}$ World KLEMS Conference

Harvard University

Cambridge, Massachusetts

August 9-10, 2012

*Office of Productivity and Technology, Bureau of Labor Statistics, U.S. Department of Labor;

Washington, DC 20212. Contacts: Susan Fleck, Email: fleck.susan@bls.gov, Steven Rosenthal, Email: rosenthal.steven@bls.gov, and Lisa Usher, Email: usher.lisa@bls.gov

** Industry Economic Accounts, Bureau of Economic Analysis, U.S. Department of Commerce; Washington, DC 20230. Contacts, Matthew Russell, Email: matthew.russell@bea.gov, Erich H. Strassner, Email: Erich.Strassner@bea.gov

The views expressed in this paper are solely those of the authors and are not necessarily those of the Bureau of Economic Analysis, U.S. Department of Commerce and Bureau of Labor Statistics, U.S. Department of Labor. 


\section{A Prototype BEA/BLS Industry-Level Production Account for the United States ${ }^{* * *}$}

By Susan Fleck, Steven Rosenthal, Matthew Russell, Erich H. Strassner, and Lisa Usher In recent years, much interest has been paid to structural changes at the industry level in the United States economy and their implications for competitiveness. The most-recent business cycle and subsequent recovery have furthered these interests in understanding the sources of economic growth, including output, input, and multifactor productivity (MFP) growth across all industries-both goods- and services-producing industries-in the U.S. economy.

Gross Domestic Product (GDP) by Industry statistics provide detailed information on the industry sources of aggregate value added growth, but do not include estimates of the contributions of capital and labor inputs and MFP to economic growth. MFP measures the output per unit of capital, labor, and intermediate inputs, and is an important component of growth in GDP. MFP growth is calculated as the growth that cannot be explained by changes in the combined contribution of these factor inputs. The official MFP measures provide information on components of economic growth in the market economy; but they do not report detailed information on the nonmarket economy. While these two sets of statistics share a common economic accounting framework; in the United States, they are prepared by two separate agencies. GDP statistics are published by the Bureau of Economic Analysis (BEA), U.S. Department of Commerce and MFP and labor productivity statistics are published by the Bureau of Labor Statistics (BLS), U.S. Department of Labor. Differences in concepts and methods used by each agency persist due to the different nature of each program, but each statistical program depends on the other to prepare its measures.

This paper builds on the GDP by industry statistics produced by the BEA and the capital, labor and MFP statistics produced by the BLS to assemble an industry-level production account for the United States that is consistent with GDP. The key feature of this internally-consistent

\footnotetext{
*** We thank Billy Jolliff, Sarah Osborne, and Peter Kuhbach of the Bureau of Economic Analysis and Kevin Delaney, Mark Dumas, Bhavani Khandrika, and Randall Kinoshita of the Bureau of Labor Statistics for substantial contributions to the development of this prototype account. Carol E. Moylan of BEA and John Ruser of BLS provided valuable guidance to this project. We are also grateful to Dale Jorgenson, Mun Ho, and Jon Samuels for their advice and consultation throughout this project and also for sharing underlying datasets from their work which proved to be of great benefit in developing this account.
} 
prototype account is to provide values, prices, and quantities of outputs and inputs used in the industry production process. This set of accounts allows one to decompose the industry contributions of inputs and MFP to the sources of GDP growth at the aggregate level.

Productivity statistics integrated with National Economic Accounts' GDP statistics have long been sought to provide a rich source of information for policy makers, business analysts, and economists. The usefulness of such integrated analysis on the sources of growth within the framework of the U.S. national income and product accounts (NIPAs) was first presented by Jorgenson and Landefeld (2006) in A New Architecture for the U.S. National Accounts.

This effort is the latest in a series of collaborations that was formalized in 2002 between the BEA and the BLS to better harmonize and reconcile GDP, GDP by industry, and productivity statistics. Early work involved reconciling price differences between the two agency's measures of industry output to improve industry comparisons. Fraumeni, Harper, Powers, and Yuskavage (FHPY) (2006) detailed the agency collaborations toward reconciling output measures where common data sources were used; the authors also developed a conceptual framework and illustrative production account for the nonfarm business sector. An important step undertaken by BEA around this time involved integrating the National Accounts' GDP statistics with the annual GDP by industry and input-output statistics (Moyer et al. 2004, Lawson et al. 2006). Subsequently, Strassner, Medeiros, and Smith (2005) of BEA produced detailed KLEMS (Kcapital, L-labor, E-energy, M-materials, and S-purchased services) estimates of inputs within the framework of the integrated Industry Accounts. Harper, Moulton, Rosenthal, and Wasshausen (2008) first implemented an integrated production account for the private business sector as outlined by FHPY (2006), made recommendations of how to expand the production account to cover the total economy, and presented alternative rental prices to improve the measurement of capital services for the nonmarket economy. ${ }^{1}$ Most recently, Harper, Khandrika, Kinoshita,

\footnotetext{
${ }^{1}$ This analysis laid the groundwork for BLS to produce total economy measures of output per unit of input that included the coverage of non-market production by government and nonprofit institutions. The study also developed cross-agency understanding of the methodological differences between BLS private business measures and BEA GDP. Improved data tables with these measures are now updated on a periodic basis by both agencies "Summary Integrated Production Account Tables (April 21, 2011) are available at http://bea.gov/national/integrated prod.htm. "1987-2010 Total Economy Production Account Tables' are available at http://www.bls.gov/mfp/mprdload.htm.
} 
and Rosenthal (2010) of BLS integrated the BEA KLEMS statistics to publish BLS nonmanufacturing MFP measures. ${ }^{2}$

This paper builds on these previous efforts by developing a prototype BEA/BLS industry-level production account for the period 1998-2010 on a 2002 North American Industry Classification (NAICS) basis. The account incorporates gross output, value added, and intermediate inputsincluding energy, materials, and purchased services - statistics by industry from the BEA, and labor and capital input measures by industry from BLS. BEA data are consistent with the Industry Accounts' statistics as of December 2011. The BLS labor and capital measures were also produced in 2011, and reflect adjustments that were made where necessary to provide consistency in concepts and coverage for this prototype account. ${ }^{3}$

We present contributions of KLEMS inputs and MFP to gross output growth at roughly the 3digit NAICS level of industry detail based on a gross-output production accounting framework. ${ }^{4}$ The gross output concept differs from the sectoral concept used by the BLS in its industry-level MFP statistics. The sectoral approach excludes intermediate production and purchases that come from within the industry (i.e., intra-industry transactions) from both output and inputs. This is the primary conceptual difference between the MFP measures presented here and the official BLS productivity statistics. ${ }^{5}$ Both approaches are discussed in Schreyer (2001).

We use the gross-output approach in this prototype, industry-level production account because it provides a clear crosswalk to published BEA GDP, GDP by industry, and Input-Output statistics, including estimates of gross output, value added, and intermediate inputs by industry. The starting point for this prototype production account is the fundamental economic accounting identity that under the zero profit assumption, the value of gross output equals the

\footnotetext{
${ }^{2}$ This article also presented Domar percentage-point contributions of these industries and sectors to private business multifactor productivity growth.

${ }^{3}$ BLS regularly publishes labor and capital measures that are consistent with NIPA industry-level definitions, but with differences in coverage and concepts that will be discussed later in this paper. For this account, we incorporate data across all legal forms of organization at the industry level to ensure consistency with GDP. ${ }^{4}$ Jorgenson, Gollop, and Fraumeni (1987) and Jorgenson, Ho, and Stiroh (2005) rely on gross output measures. ${ }^{5}$ The National Academy of Sciences (1979) (Reese) Panel to Review Productivity Statistics recommended a sectoral framework for measuring productivity. Aggregating industry-level sectoral output to the total economy produces value-added output. The sectoral framework provides a unifying rationale of output measurement from detailed industry to major sectors.
} 
value of payments for KLEMS inputs to production, including intra-industry transactions. ${ }^{6}$ The complete set of accounts that we present in this paper decomposes changes in these values over time into changes in prices and changes in quantities, thus permitting an index number estimate of MFP growth by industry. This study also includes estimates of the Domar-weighted contributions of industry MFP to economy-wide MFP. We also include illustrative results of a labor composition adjustment to BLS labor hours for purposes of understanding its impact on estimating the contribution of labor input and MFP by industry. ${ }^{7}$ This adjustment for labor composition reflects the heterogeneity of each industry's workforce and yields a symmetric treatment of labor and capital services in this prototype, production account.

The remainder of the paper proceeds in five sections. We provide a first look at prototype industry-level results. We present BLS MFP productivity measures and compare them with the industry production account results. We describe the methodology for this prototype industrylevel account, including a description of how the various datasets are compiled. We discuss some of the conceptual and estimation challenges that require resolution before this account can be released on a regular basis. Lastly, we conclude with comments on possible future work and next steps in this important collaboration.

\section{A FIRST LOOK AT PROTOTYPE RESULTS}

An important contribution of this prototype, BEA/BLS industry-level production account is that it can be used to trace the sources of U.S. economic growth across all goods- and servicesproducing industries in the U.S. economy. This prototype, integrated account presents the contributions of both value added and intermediate input factors of production, and also the contribution of MFP to U.S. real gross output growth, at roughly the 3-digit NAICS industry level as published in the U.S. Industry Economic Accounts. This section highlights the sources of U.S.

\footnotetext{
${ }^{6}$ Intra-industry purchases can be a relatively important source of production for certain industries; for example, the Semiconductor industry relies heavily on intra-industry transactions to produce microprocessor chips.

${ }^{7}$ Domar weights consist of a ratio of current dollar gross output divided by aggregate value added. These weights are unique in that they sum to more than one, reflecting the fact that an increase in an industry's productivity has a direct effect on the industry's output as well a secondary effect through the output of one industry delivered to another as intermediate inputs.
} 
economic growth over the period 1998-2010, including MFP trends during this period at the industry level, and also details the contributions of each industry's MFP to economy-wide MFP.

Sources of U.S. Output Growth, 1998-2010

With the development of a prototype industry-level production account spanning all industries integrated within an Input-Output framework, useful information can be generated by tracing the sources of output growth across each industry's KLEMS inputs-both its primary, value added inputs, and its secondary, intermediate inputs-and to MFP. Table A further demonstrates the usefulness of such integrated analysis within a framework that is consistent with GDP, by presenting the sources of aggregate value added growth for the United States that are attributable to the primary, value added inputs of capital and labor, and to MFP.

\begin{tabular}{l|r|}
\hline \multicolumn{2}{|c|}{ Table A: Aggregate factor contributions to GDP Growth, 1998-2010 } \\
\hline All Industry Value-Added Growth & 1.90 \\
Aggregate Labor Contribution & 0.20 \\
College Graduate & 0.46 \\
No College Degree & -0.25 \\
Aggregate Capital Contribution & 1.15 \\
Aggregate MFP Growth & 0.56 \\
\hline *Growth is expressed as the difference in natural logs. Individual components \\
may not sum to totals due to rounding
\end{tabular}

Industry contributions for each input and MFP were generated and evaluated over several periods. The contributions from at least one of the primary, value added inputs of capital and labor, or secondary, intermediate inputs of energy, materials, and purchased services were greater than MFP growth in more than 75 percent of the 63 industries included in this account.

In the top three industries with the largest percent changes in gross output-positive or negative-intermediate input contributions were the largest contributor to the percent changes in gross output, reflecting its relative weight as a well as recent trends in the sourcing of production (Table B). In six of the top 10 industries with the strongest output growth, intermediate inputs were the most significant factor. Negative intermediate input contributions were the largest contributor in all but one of the ten industries that showed the largest output decline (Table 3). 
Rental and leasing and information and data processing services, two capital-intensive industries, were among the industries with the largest capital contributions to output growth. The capital contribution of rental and leasing was 2.89 percentage points to output growth of 1.7 percent. Capital contributed 1.76 percentage points to real output growth of 7.8 percent for information and data processing services.

\begin{tabular}{|c|c|c|c|c|c|c|c|c|}
\hline \multicolumn{9}{|c|}{ Largest Intermediate Contributions } \\
\hline Description & Capital & Labor & Intermediate & Energy & Material & Service & MFP & Output \\
\hline Support activities for mining & 0.13 & 0.78 & 6.26 & 0.27 & 2.98 & 3.01 & 1.70 & 8.86 \\
\hline Securities, commodity contracts, investments & -0.39 & 0.85 & 5.36 & -0.02 & 0.10 & 5.28 & 2.52 & 8.33 \\
\hline Information and data processing services & 1.76 & 0.34 & 3.93 & 0.03 & 0.60 & 3.31 & 1.77 & 7.81 \\
\hline Federal Government & 0.10 & 0.36 & 2.23 & 0.04 & 0.26 & 1.92 & 0.22 & 2.90 \\
\hline Federal Reserve banks, credit intermediation, and related activities & 1.38 & 0.12 & 1.93 & 0.00 & 0.03 & 1.90 & 0.67 & 4.10 \\
\hline \multicolumn{9}{|c|}{ Largest Capital Contributions } \\
\hline Description & Capital & Labor & Intermediate & Energy & Material & Service & MFP & Output \\
\hline Rental and leasing services and lessors of intangible assets & 2.89 & -0.11 & 0.22 & -0.02 & 0.00 & 0.24 & -1.31 & 1.69 \\
\hline Information and data processing services & 1.76 & 0.34 & 3.93 & 0.03 & 0.60 & 3.31 & 1.77 & 7.81 \\
\hline Legal services & 1.68 & 0.39 & -0.33 & -0.01 & -0.05 & -0.27 & -1.80 & -0.06 \\
\hline Broadcasting and telecommunication & 1.66 & -0.36 & 1.35 & -0.01 & 0.28 & 1.08 & 1.79 & 4.44 \\
\hline Publishing & 1.62 & -0.41 & 1.05 & -0.02 & -0.09 & 1.16 & 0.16 & 2.43 \\
\hline \multicolumn{9}{|c|}{ Largest Labor Contributions } \\
\hline Description & Capital & Labor & Intermediate & Energy & Material & Service & MFP & Output \\
\hline Computer systems design and related services & -0.13 & 2.30 & 1.54 & -0.01 & 0.28 & 1.26 & 2.52 & 6.23 \\
\hline Educational services & 0.21 & 1.67 & 0.96 & 0.03 & 0.16 & 0.77 & -1.19 & 1.65 \\
\hline Ambulatory health care services & 0.29 & 1.60 & 0.85 & 0.00 & 0.11 & 0.73 & 0.53 & 3.27 \\
\hline Warehousing and storage & 0.39 & 1.52 & 1.67 & 0.11 & 0.20 & 1.37 & 0.27 & 3.86 \\
\hline Management of companies and enterprises & 1.19 & 1.44 & 1.01 & 0.00 & 0.20 & 0.81 & -2.54 & 1.11 \\
\hline
\end{tabular}

Similarly, several labor-intensive industries had the highest labor contribution to output growth (see Table B and Table 3 in the appendix). Computer systems design and related services, education services, and ambulatory health care services were among the industries with the largest labor contributions to output growth.

In the top 10 industries ranked by size of workforce for 2010, the sources of output growth were mixed (Table C). Among the largest employment industries ranked by size of employment, labor was the greatest input contribution for state and local government, at 0.83 percentage point and in ambulatory health care services, at 1.60 percentage points. Among these 10 industries, wholesale trade and retail trade were the industries which showed the 
greatest capital contributions as the largest contributor to output growth. ${ }^{8}$ The intermediate inputs contribution was the largest contributor to output growth in federal government at 2.23 percentage points, led by the contribution of purchased-services inputs. In food services and drinking places, the intermediate input contribution of 0.74 percentage point was also led by purchased-services inputs. In hospitals and nursing and residential care facilities, the intermediate inputs contribution of 1.70 percentage points was also the most significant contributor to output growth, with, once again, purchased-services inputs accounting for the largest contribution. MFP growth or declines were the largest contributors to output growth or declines in administrative and support services at 1.22 percentage points, other services at 1.33 percentage points, and construction, at -1.33 percentage points for these selected industries.

\begin{tabular}{|c|c|c|c|c|c|c|c|c|c|}
\hline $\begin{array}{c}2010 \\
\text { Employment }\end{array}$ & Description & Capital & Labor & Intermediates & Energy & Material & Service & MFP & Output \\
\hline 19541 & State and local & 0.19 & 0.83 & 0.68 & 0.01 & 0.12 & 0.55 & -0.40 & 1.30 \\
\hline 14743 & Retail trade & 0.99 & -0.08 & 0.83 & -0.03 & 0.27 & 0.59 & 0.31 & 2.05 \\
\hline 9506 & Food services and drinking places & -0.04 & 0.47 & 0.74 & 0.01 & 0.00 & 0.72 & 0.45 & 1.63 \\
\hline 7818 & Hospitals and nursing and residential care facilities & 0.27 & 0.96 & 1.70 & 0.02 & 0.11 & 1.57 & -0.13 & 2.79 \\
\hline 7150 & Administrative and support services & 0.81 & -0.22 & -0.08 & 0.00 & 0.04 & -0.11 & 1.22 & 1.72 \\
\hline 6743 & Other services, except government & 0.41 & 0.22 & 0.44 & -0.02 & -0.18 & 0.65 & -1.33 & -0.26 \\
\hline 6024 & Ambulatory health care services & 0.29 & 1.60 & 0.85 & 0.00 & 0.11 & 0.73 & 0.53 & 3.27 \\
\hline 5767 & Construction & 0.34 & -0.30 & -1.12 & -0.03 & -0.93 & -0.16 & -1.33 & -2.41 \\
\hline 5520 & Wholesale trade & 0.92 & -0.17 & 1.21 & 0.00 & 0.28 & 0.93 & 0.76 & 2.71 \\
\hline 5425 & Federal & 0.10 & 0.36 & 2.23 & 0.04 & 0.26 & 1.92 & 0.22 & 2.90 \\
\hline
\end{tabular}

\section{Labor composition}

In this prototype, we decompose the labor contributions to output growth into demographic characteristics that account for the contributions of the college-educated workforce and those workers that did not attend college. This adjustment to labor input allows for the contribution of labor to reflect changes in the composition of the skill level of the labor force over time, in addition to the number of hours worked by industry.

\footnotetext{
${ }^{8}$ Wholesale and Retail trade output measures reflect the gross margin output concept, which subtracts the costs of goods sold from its sales and inventories and therefore also excludes them from its input costs.
} 
In over 80 percent of the industries measured, the contributions from the college workforce were higher than those that did not attend college, reflecting the industries' shift in demand toward college educated workers (see Table 4 in the appendix). The median contribution of workers with a college education was 0.07 percentage point while the non-college educated workers' subtracted 0.19 percentage point from economy-wide output growth over the period 1998-2010.

\begin{tabular}{l|r|r|r}
\hline \multicolumn{3}{c}{ Table D: Labor Contribution, 1998-2010 [percentage point] } \\
\hline & College Labor & No College Labor & Labor Composition \\
\hline \multicolumn{4}{c}{ No College Largest Contributions } \\
\hline Warehousing and storage & 0.26 & 1.27 & 1.52 \\
Social assistance & 0.36 & 0.20 & 1.07 \\
Ambulatory health care services & 1.07 & 0.53 & 1.60 \\
\hline \multicolumn{4}{c}{ College Largest Contributions } \\
\hline Management of companies and enterprises & 2.42 & -0.88 & 1.44 \\
Computer systems design and related services & 2.10 & 0.20 & 2.30 \\
Educational services & 1.52 & 0.16 & 1.67 \\
\hline
\end{tabular}

Ranking the industries by college educated contributions shows that computer systems design and related services, management of companies and enterprises, and education services have the largest labor contributions to output growth (Table D).

Warehousing and storage, social assistance, and administrative and support services had the highest labor contributions of non-college-educated labor to output growth.

MFP growth trends at the industry level

"High-tech" industries showed some of the strongest MFP growth over the period 1998-2010 (Table E). Computer and electronic product manufacturing, information and data processing services, computer systems design and related services, and broadcasting and telecommunications were among the industries with the largest MFP growth. These Information-communications-technology-producing industries were among the top 10 industries with MFP growth. 


\begin{tabular}{l|r|r|r|r}
\hline \multicolumn{4}{c}{ Table E: Multifactor Productivity Growth for Selected Industries [percent change] } \\
\hline Description & $1998-2000$ & $2000-2007$ & $2007-2010$ & $1998-2010$ \\
\hline Computer and electronic product manufacturing & 12.2 & 8.5 & 10.7 & 9.6 \\
Computer systems design and related services & -0.5 & 3.1 & 3.2 & 2.5 \\
Broadcasting and telecommunication & -0.1 & 2.8 & 0.6 & 1.8 \\
Information and data processing services & -13.0 & 6.4 & 0.8 & 1.8 \\
Oil and gas extraction & -12.8 & -1.0 & 0.1 & -2.7 \\
Management of companies and enterprises & -0.3 & -2.6 & -3.8 & -2.5 \\
Legal services & 0.2 & -2.1 & -2.4 & -1.8 \\
Securities, commodity contracts, investments & 5.3 & 1.0 & 4.2 & 2.5 \\
Apparel and leather and allied products & 1.2 & 1.3 & 11.8 & 3.9 \\
Construction & -0.6 & -2.2 & 0.2 & -1.3 \\
\hline
\end{tabular}

From 1998-2010, computer and electronic products manufacturing led MFP growth at an average annual rate of 9.6 percent (See Table 2 in the appendix). This MFP growth was driven by rising output, at a 5.5 percent average annual rate, and falling intermediate inputs, at a 6.6 percent average annual rate. Computer systems design and related services MFP grew 2.5 percent at an average annual rate, driven by strong output growth. Oil and gas extraction showed the largest MFP decline during the period, falling at an average annual rate of 2.7 percent, driven by intermediate inputs growth of 2.2 percent. Management of companies and enterprises and legal services were also among the industries with the largest average annual declines in MFP, decreasing 2.5 percent and 1.8 percent at average annual rates, respectively.

\section{Contributions to economy-wide MFP}

From 1998-2010, the economy-wide MFP grew at an average annual rate of 0.56 percent. Both goods-producing industries and services-providing industries had positive contributions to aggregate MFP growth through the period 1998-2010. Services- producing industries contributed about 0.23 percentage point to the economy-wide MFP while goods-producing industries contributed 0.33 percentage point.

From 2000-2007, economy-wide MFP increased at an average annual rate of 0.61 percent, while MFP increased at an average annual rate of 0.17percent from 2007-2010. The goodsproducing sector accounted for more of the increase in MFP, adding 0.14 percentage point of the 0.17 percentage point increase from 2007-2010. 


\section{Goods-producing sector ${ }^{9}$ contributions to economy-wide MFP}

From 1998-2010, computer and electronic products manufacturing contributed 0.33 percentage point to economy-wide MFP, significantly more than any other industry (Table F). The Farms industry was a distant second within the goods-producing sector, contributing 0.04 percentage point to the increase in economy-wide MFP. Miscellaneous manufacturing was also among the leading contributors, adding 0.02 percentage point to economy-wide MFP.

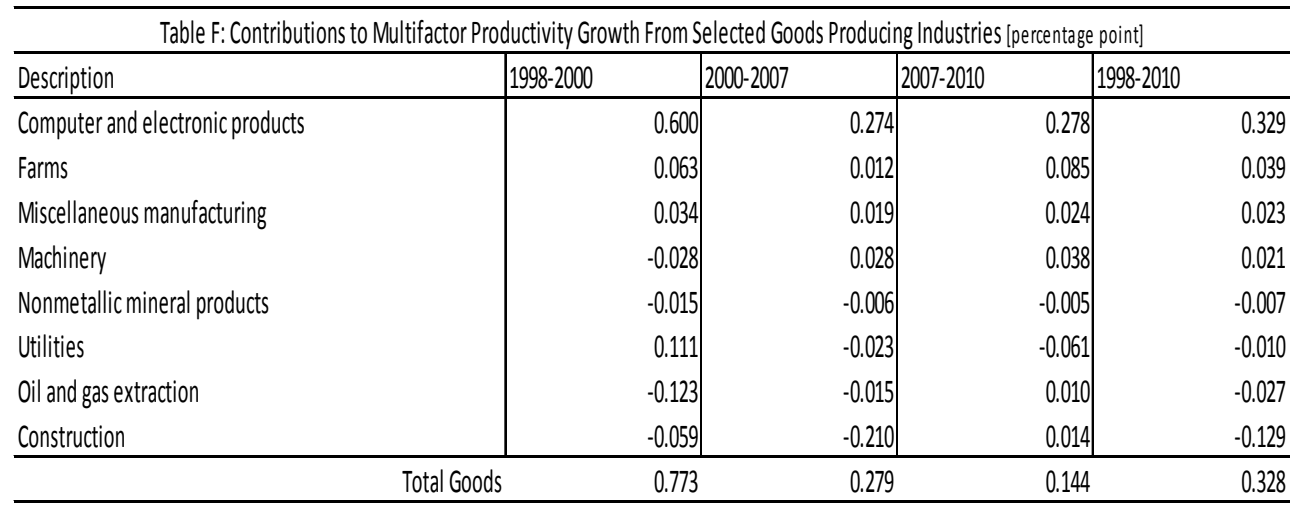

The contribution of computer and electronic products manufacturing to economy-wide MFP growth experienced a leveling-off in recent years. Over the period studied, the contributions from computer and electronic products manufacturing were the greatest in the 1998-2000 period, 0.60 percentage point; in the more recent period of 2007-2010, the contribution was 0.28 percentage point. This trend is consistent with BLS estimates of the contributions of 3digit manufacturing industries to private non-farm business MFP. ${ }^{10}$ The trend also confirms the accepted story of an IT-induced productivity speed-up in the last half of the 1990s.

\section{Services-producing sector ${ }^{11}$ contributions to economy-wide MFP}

From 1998-2010, the securities, commodity contracts, and investments and broadcasting and telecommunications industries were among the top contributors to economy-wide MFP

\footnotetext{
${ }^{9}$ In the U.S. Industry Economic Accounts, the goods-producing sector consists of agriculture, forestry, fishing, and hunting; mining; construction; and manufacturing.

${ }^{10}$ See http://www.bls.gov/mfp/mfgcon.pdf, Bureau of Labor Statistics (2012).

${ }^{11}$ In the U.S. Industry Economic Accounts, the services-producing sector consists of utilities; wholesale trade; retail trade; transportation and warehousing; information; finance, insurance, real estate, rental, and leasing; professional and business services; educational services, health care, and social assistance; arts, entertainment, recreation, accommodation, and food services; and other services, except government.
} 
growth, with securities, commodity contracts, and investments contributing the most, 0.08 percentage point (Table G).

During the 2000-2007 sub-period, all services-producing sector related informationcommunications-technology producing industries added to economy-wide MFP growth, including publishing (which includes software publishing), broadcasting and telecommunications, information and data processing services, and computer systems design and related services. Wholesale trade was also among the largest contributors to MFP growth, contributing 0.11 percentage point to economy-wide MFP growth during this period.

\begin{tabular}{l|r|r|r|r}
\hline \multicolumn{1}{c}{ Table G: Contributions to Multifactor Productivity Growth From Selected Service Providing Industries [percentage point] } \\
\hline Description & $1998-2000$ & $2000-2007$ & $2007-2010$ & $1998-2010$ \\
\hline Securities, commodity contracts, and investments & 0.167 & 0.033 & 0.145 & 0.084 \\
Broadcasting and telecommunications & -0.004 & 0.129 & 0.026 & 0.081 \\
Wholesale trade & 0.179 & 0.111 & -0.114 & 0.066 \\
Administrative and support services & -0.012 & 0.061 & 0.057 & 0.048 \\
Federal Reserve banks, credit intermediation, and related activities & 0.020 & -0.006 & 0.171 & 0.043 \\
Computer systems design and related services & -0.008 & 0.048 & 0.057 & 0.041 \\
Information and data processing services & -0.094 & 0.057 & 0.007 & 0.019 \\
Publishing industries (includes software) & -0.115 & 0.041 & -0.009 & 0.002 \\
Real estate & 0.193 & -0.018 & -0.235 & -0.037 \\
State and local & -0.059 & -0.064 & -0.029 & -0.055 \\
Other services, except government & -0.021 & -0.065 & -0.059 & -0.056 \\
Management of companies and enterprises & -0.008 & -0.068 & -0.104 & -0.067 \\
\hline \multicolumn{2}{c}{ Total Service } & 0.155 & 0.335 & 0.028 \\
\hline
\end{tabular}

From 2007-2010, Federal Reserve banks, credit intermediation, and related activities led the increase in aggregate MFP, adding 0.17 percentage point to MFP growth. Credit intermediation, and related activities and securities, commodity contracts, and investments, was also among the largest contributors to the increase in MFP over this period, increasing aggregate MFP growth by 0.14 percentage point. These positive contributions were partly offset by negative contributions by the real estate industry, which subtracted 0.23 percentage point.

\section{BLS MFP and Industry Contributions to BLS MFP- a comparison}

The output measures used in the BLS MFP measures are constructed to be as consistent as possible with the BLS major sector labor productivity measures (except that the MFP measures exclude government enterprises). This consistency allows BLS MFP data to help explain the sources of growth in the official labor productivity series. In a model where capital and labor are the measured inputs, sources of labor productivity growth include increases in capital 
intensity (i.e., capital deepening) and improvements in the skills of the labor force (i.e., labor composition). Additional sources of labor productivity are attributed to multifactor productivity, which may reflect changes in a variety of factors that are not included as measured inputs, including technology change, economies of scale, and improvements in management techniques or organization of production, among other factors.

For BLS official estimates of private business and private nonfarm business MFP, the relationship of aggregate multifactor productivity to aggregate labor productivity is given by the following equation:

$$
d(\ln Y-\ln L)=d \ln A+w_{k}[d(\ln K-\ln L)]+w_{l}[d \ln L C]
$$

where:

Y=output

L=labor

$\mathrm{K}=$ capital

LC=labor composition

$\mathrm{d}$ denotes the derivative with respect to time

$w_{i}$ denotes the cost share weight of input $i,(i=k, l)$

This equation shows that labor productivity growth is decomposed into the contribution of multifactor productivity growth, the contribution resulting from $\mathrm{K} / \mathrm{L}$ substitution (capital deepening) and the contribution of the labor composition effect. This relationship between MFP and labor productivity ties the private business and private nonfarm business MFP measures to the official published estimates of business and nonfarm business labor productivity, with the caveat that government enterprises is excluded.

Furthermore, the BLS industry contributions roughly sum to the official published estimates of private business and private nonfarm business MFP. When compared to the industry-level Domar contributions to economy-wide MFP for the industry production account measures presented in this paper, the industry-level Domar contributions to private business sector MFP are comparable in magnitude and order. Table $\mathrm{H}$ below shows BLS multifactor productivity 
growth for selected industries. For tables I and J, the Domar weighting scheme is applied based on the relative importance of each industry to total private business MFP.

\section{BLS MFP growth rates for selected industries}

Table $\mathrm{H}$ shows that the BLS MFP growth rates for selected industries are similar to the industry production account MFP growth rates. One major exception is the 2007-2010 MFP growth rate for apparel and leather and applied products. Computer and electronic products similarly show the largest MFP growth of these industries, an average annual rate of $11.0 \%$ for the $1998-2010$ period.

Table H: BLS Multifactor Productivity Growth for Selected Industries

\begin{tabular}{|c|c|c|c|c|}
\hline Description & $1998-2000$ & $2000-2007$ & $2007-2010$ & $1998-2010$ \\
\hline Computer and Electronic Products & 14.1 & 9.9 & 11.7 & 11.0 \\
\hline Computer Systems Design and Related Services & -1.1 & 3.1 & 3.3 & 2.4 \\
\hline Broadcasting and Telecommunications & 0.4 & 3.3 & 0.5 & 2.1 \\
\hline Information and Data Processing Services & -15.3 & 5.6 & 1.1 & 0.7 \\
\hline Oil and Gas Extraction & -9.3 & -0.6 & -0.2 & -2.0 \\
\hline Management of Companies and Enterprises & 0.6 & -1.1 & -2.5 & -1.2 \\
\hline Legal Services & 1.3 & -0.1 & -1.0 & -0.1 \\
\hline Securities, Commodity Contracts, and Investments & 8.6 & 2.0 & 2.5 & 3.2 \\
\hline Apparel and Leather and Applied Products & 2.6 & 4.2 & 2.6 & 3.6 \\
\hline Construction & -0.2 & -2.0 & 0.7 & -1.0 \\
\hline
\end{tabular}


Goods-producing sector contributions to BLS private business MFP

For the 1998-2010 period, the industry contributions to BLS private business MFP show similar results to the industry production account contributions. As expected, computer and electronic products dominate the contributions to private business MFP, 0.43 percentage points, approximately a third of the total MFP growth rate for the 1998-2010 period.

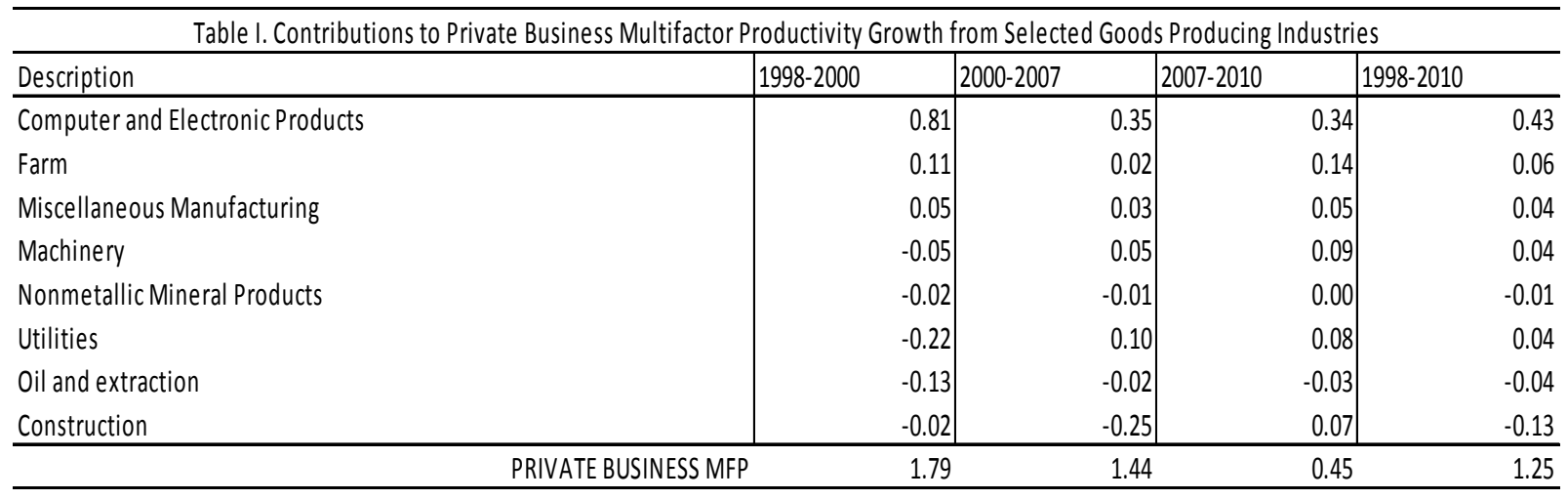

Services-producing sector contributions to BLS private business MFP

As in the industry production account measures, securities, commodity contracts, and investments, broadcasting and telecommunications, and wholesale trade show the highest contributions to private business multifactor productivity growth.

Table J: Contributions to Private Business Multifactor Productivity Growth from Selected Services Providing Industries

\begin{tabular}{l|r|r|r|r}
\hline Description & $1998-2000$ & $2000-2007$ & $2007-2010$ & $1998-2010$ \\
\hline Securities, commodity contracts, and investments & 0.38 & 0.08 & 0.16 & 0.15 \\
Broadcasting and telecommunications & 0.02 & 0.19 & 0.03 & 0.12 \\
Wholesale trade & 0.19 & 0.19 & -0.12 & 0.11 \\
Administrative and Support Services & 0.01 & 0.07 & 0.04 & 0.05 \\
Federal Reserve banks, credit intermediation, and related activities & 0.09 & -0.01 & 0.24 & 0.07 \\
Computer systems design and related services & -0.02 & 0.06 & 0.08 & 0.05 \\
Information and data processing services & -0.16 & 0.08 & 0.01 & 0.02 \\
Publishing industries (includes software) & -0.11 & 0.08 & -0.01 & 0.03 \\
Real Estate & 0.18 & 0.06 & -0.31 & -0.01 \\
Other Service, except Government & 0.04 & -0.05 & -0.04 & -0.03 \\
Management of Companies and Enterprises & 0.02 & -0.04 & -0.10 & -0.05 \\
\hline
\end{tabular}


Table K shows the largest positive differences between BLS MFP and the industry production account MFP. Table L highlights the difference between BLS sectoral output and BEA gross output measures. For half of the measures, the conceptual difference between the output measures explains most of the difference in MFP growth. A major exception is computer and electronic products. The difference for this sector is primarily due to differences in the way intermediate inputs are calculated. BLS excludes intraindustry transactions in its sectoral approach - i.e. BLS excludes sales between establishments within the same industry from both output and intermediate purchases.

\begin{tabular}{|c|c|c|c|}
\hline \multicolumn{4}{|c|}{$\begin{array}{r}\text { Table K: Seven Largest Positive Differences in Annual Percent Chan } \\
\text { Measure by Industry, 1998-2010 (BLS MFP less BEA MFP) }\end{array}$} \\
\hline \multicolumn{2}{|l|}{ Description } & \multicolumn{2}{|c|}{$1998-2010$} \\
\hline \multicolumn{2}{|l|}{ Air transportation } & \multicolumn{2}{|r|}{2.5} \\
\hline \multicolumn{2}{|l|}{ Legal services } & \multicolumn{2}{|r|}{1.7} \\
\hline \multicolumn{2}{|l|}{ Utilities } & \multicolumn{2}{|r|}{1.4} \\
\hline \multicolumn{2}{|l|}{ Computer and electronic products } & \multicolumn{2}{|r|}{1.4} \\
\hline \multicolumn{2}{|c|}{ Management of companies and enterprises } & \multicolumn{2}{|r|}{1.3} \\
\hline \multicolumn{2}{|c|}{ Educational services } & \multicolumn{2}{|r|}{0.9} \\
\hline \multicolumn{2}{|l|}{ Insurance carriers and related activities } & \multicolumn{2}{|r|}{0.8} \\
\hline \multicolumn{4}{|c|}{ Table L: Differences in Output Measures } \\
\hline Description & $\begin{array}{c}\text { BLS } \\
\text { Sectoral Output } \\
(1998-2010) \\
\end{array}$ & $\begin{array}{c}\text { BEA } \\
\text { Gross Output } \\
(1998-2010) \\
\end{array}$ & Difference \\
\hline Air transportation & 1.8 & -0.3 & 2.1 \\
\hline Legal services & 0.1 & -0.1 & 0.2 \\
\hline Utilities & -0.1 & -1.4 & 1.3 \\
\hline Computer and electronic product manufact & 3.9 & 5.5 & -1.6 \\
\hline Management of companies and enterprises & 1.5 & 1.1 & 0.4 \\
\hline Educational services & 2.6 & 1.7 & 0.9 \\
\hline Insurance carriers and related activities & 3.1 & 1.6 & 1.5 \\
\hline
\end{tabular}

Table $\mathrm{M}$ shows the largest negative differences between BLS and the production accounts MFP. Table $\mathrm{N}$ shows the differences between sectoral output and gross output measures. Some of 
the differences in MFP between the industries are due to the difference in output measures. The rest are attributable to differences in intermediate inputs.

Table M: Seven Largest Negative Differences in Annual Percent Change in MFP Measure by Industry, 1998-2010 (BLS MFP less BEA MFP)

\begin{tabular}{l|r} 
Description & $1998-2010$ \\
\hline Funds, trusts, and other financial vehicles & -1.6 \\
Information and data processing services & -1.1 \\
Petroleum and coal products & -0.6 \\
Accommodation & -0.6 \\
Textile mills and textile product mills & -0.5 \\
Mining, except oil and gas & -0.4 \\
Apparel and leather and applied products & -0.3 \\
\hline
\end{tabular}

Table N: Differences in Output Measures

\begin{tabular}{l|r|r|r}
\hline Description & $\begin{array}{c}\text { Sectoral Output } \\
\text { (1998-2010) }\end{array}$ & $\begin{array}{c}\text { Gross Output } \\
(1998-2010)\end{array}$ & Difference \\
\hline Funds, trusts, and other financial vehicles & 2.6 & 2.6 & 0.0 \\
Information and data processing services & 8.3 & 7.8 & 0.5 \\
Petroleum and coal products & 0.7 & 1.4 & -0.7 \\
Accommodation & 1.3 & 2.6 & -1.3 \\
Textile mills and textile product mills & -5.5 & -5.9 & 0.4 \\
Mining, except oil and gas & -1.2 & -1.2 & 0.0 \\
Apparel and leather and applied products & -12.8 & -12.3 & -0.5 \\
\hline
\end{tabular}

\section{METHODOLOGY}

This section provides a brief overview of the conceptual framework and estimation methods used to prepare the prototype BEA/BLS industry-level production account. We provide a description of the gross-output growth accounting framework, discuss the estimation methods used to prepare our results, and summarize the source data methods used by BEA and BLS to 
produce the gross output, value added, intermediate inputs, capital input, and labor input used in this account, including adjustments we made to achieve better integration of these datasets.

\section{Conceptual Overview of Measurement}

For the prototype BEA/BLS production account framework, we assume the following type of production function relating gross output of an industry to three factor inputs using the gross output production function model: $Q=F(K, L, I I, t)$ where $K$ stands for capital, $L$ stands for Labor, II stands for the intermediate inputs. ${ }^{12,13}$

Under the assumption of constant returns to scale, perfect competition, and factors being paid their marginal product, the gross-output growth model can be rearranged in terms of MFP growth computed in the following, simplified way.

1. $\frac{\mathrm{d} \ln Q}{\mathrm{dt}}=\left(\frac{\partial \ln Q}{\partial \ln K} * \frac{\mathrm{d} \ln K}{\mathrm{dt}}\right)+\left(\frac{\partial \ln Q}{\partial \ln I I} * \frac{\mathrm{d} \ln I \mathrm{I}}{\mathrm{dt}}\right)+\left(\frac{\partial \ln Q}{\partial \ln L} * \frac{\mathrm{d} \ln \mathrm{L}}{\mathrm{dt}}\right)+\left(\frac{\partial \ln Q}{\partial t}\right)$

where

$$
\begin{aligned}
& \mathrm{Q}=\text { Gross Output } \\
& \mathrm{K}=\text { Capital Input } \\
& \mathrm{L}=\text { Labor Input } \\
& \mathrm{II}=\text { Intermediate Inputs } \\
& \mathrm{P}_{\mathrm{K}}=\text { Price of Capital } \\
& \mathrm{P}_{\mathrm{I}}=\text { Price of Labor } \\
& \mathrm{P}_{\mathrm{ii}}=\text { Price of Intermediate Inputs } \\
& \mathrm{t}=\text { time }
\end{aligned}
$$$$
\text { 2. }\left(\frac{\partial \ln Q}{\partial t}\right)=\frac{\mathrm{d} \ln Q}{\mathrm{dt}}-\left(\frac{\partial \ln Q}{\partial \ln K} * \frac{\mathrm{d} \ln \mathrm{K}}{\mathrm{dt}}\right)-\left(\frac{\partial \ln Q}{\partial \ln I I} * \frac{\mathrm{d} \ln \mathrm{II}}{\mathrm{dt}}\right)-\left(\frac{\partial \ln Q}{\partial \ln L} * \frac{\mathrm{d} \ln \mathrm{L}}{\mathrm{dt}}\right)
$$

With the above assumptions, the unknown elasticities can be replaced with the observable factor share, $v_{i}$, for each input. Shown below is the factor share for capital input:

$$
\text { 3. } \frac{\partial \ln Q}{\partial \ln K}=\frac{P_{K} K=\text { Capital Compensation }}{\left(P_{K} K+P_{L} L+P_{I I} I I\right)=\text { Total Compensation }}=v_{K}
$$

\footnotetext{
${ }^{12}$ For simplicity, we express total intermediate inputs instead of the separate cost components of energy, materials, and purchased services.

${ }^{13}$ This model is also used by the BLS for its published measures for the business sector, with the exception that $Q$ is sectoral output and II reflects the subtraction of intra-industry inputs from intermediate inputs.
} 
The assumption of constant returns to scale ensures that the factor shares sum to one.

$$
\begin{aligned}
& \text { 4. } \frac{P_{K} K}{\left(P_{K} K+P_{L} L+P_{I I} I\right)}=v_{K} \quad \text { where } v_{K}+v_{L}+v_{I I}=1 \\
& \frac{P_{L} L}{\left(P_{K} K+P_{L} L+P_{I I} I I\right)}=v_{L} \\
& \frac{P_{I I} I I}{\left(P_{K} K+P_{L} L+P_{I I} I I\right)}=v_{I I}
\end{aligned}
$$

In discrete time, the input weights are two-year averages of the cost shares for each input in years $\mathrm{t}$ and $\mathrm{t}-1$, where $\widetilde{\mathrm{v}_{\mathrm{K}}}=\frac{1}{2} \mathrm{v}_{\mathrm{K}, \mathrm{t}}+\frac{1}{2} \mathrm{v}_{\mathrm{K}, \mathrm{t}-1}$

MFP growth can be rewritten in the following way, relating MFP growth for an industry as the residual of the difference in the growth in output and the growth in the combined inputs:

$$
\text { 5. MFP growth }=\Delta \ln Q-\widetilde{v_{K}} \Delta \ln (\mathrm{K})-\widetilde{v_{\mathrm{L}}} \Delta \ln (\mathrm{L})-\widetilde{\mathrm{V}_{\mathrm{II}}} \Delta \ln (\mathrm{II})
$$

There are no assumptions restricting individual industries in this analysis of MFP, each industry faces the above production function individually and without regard to any other industry.

\section{Estimation methods - Aggregation}

The MFP index is computed by dividing an index of real gross output by an index of combined inputs. A combined real input measure is computed within a Tornqvist index number formula that aggregates real intermediate inputs by industry for energy, materials, and purchased services with the labor and capital input using average cost shares. ${ }^{14}$

The current-dollar cost shares of the three main input components are generated using published and computed datasets. The current dollar intermediate inputs measure is a sum of the current dollar energy, material, and purchased-services expenditures of an industry from the BEA Annual Industry Accounts. The current dollar labor component is a measure of the compensation of workers in that industry. The BEA published labor compensation figures are supplemented to include the self-employed compensation estimate that is detailed in the labor

\footnotetext{
${ }^{14}$ BEA's National and Industry accounts use Fisher-ideal indexes to express official chain-type price and quantity indexes. This study follows the productivity literature and uses the Tornqvist index for aggregation.
} 
input section using the assumption that self-employed workers receive similar wages to the payrolled employees. Lastly, nominal capital compensation is computed as a residual of the value of gross output less the sum of labor compensation and intermediate input expenditures. $^{15}$

The intermediate inputs average share is an industry's current-dollar expenditure on energy, materials, and services divided by the value of gross-output production averaged over two periods. The average share for the remaining inputs is computed in a similar fashion. The KLEMS measures are Tornqvist aggregated using the average cost shares and the quantity indexes of each input.

\section{Estimation Methods - Gross Output, Value Added, and Intermediate Inputs}

The BEA Industry Accounts provide a time series of nominal and real gross output, intermediate inputs, and value added for industries defined according to the 2002 NAICS (Mayerhauser and Strassner, 2010). These accounts are integrated conceptually and statistically with final expenditures and GDP from the NIPAs, and are prepared within a balanced input-output framework that allows for integrated analysis of industry output, inputs, employment, and final demand. In 2005, these accounts were expanded to provide additional information on the composition of intermediate inputs by industry, which made these accounts more useful to observe changes in spending related to energy, materials, and purchased services (Strassner, Medeiros, and Smith 2005).

The Industry Accounts methodology can be summarized in four broad steps ${ }^{16}$ :

1. Prepare annual make tables. The make table shows the production of both primary and secondary commodities (goods and services) by industries;

2. Prepare initial annual use tables. The use table shows the consumption of commodities by industries (intermediate inputs) and by final demand, as well as the contribution of value added by industry;

3. Balance the use table; and

\footnotetext{
${ }^{15}$ This is a common assumption in productivity literature and ensures that the factor shares sum to unity.

${ }^{16}$ See Mayerhauser and Strassner (2010) for the most complete description of the Industry Accounts methodology.
} 
4. Prepare price and quantity indexes for gross output, intermediate inputs, and value added.

On an annual basis, a wide array of source data as described in Gilmore, Lyndaker, Pack and Randrianarivelo (2011) is used to update the annual time series. Nominal value added by industry estimates are available for the compensation of employees and taxes on production and imports less subsidies. The gross operating surplus component of value added by industry is derived from gross domestic income data adjusted to an establishment basis. Annual survey data available from the Census Bureau are used in updating industry and commodity gross output as well as for intermediate inputs by industry and the cost categories of energy, materials, and purchased services. Lastly, annual data are also used from the NIPAs and the BEA International Transactions Accounts for updating estimates of final expenditures to assure an integrated framework.

The balancing process ensures two simultaneous conditions. First, that each industry's output equals its intermediate inputs plus its value-added components, and second, that the sum of intermediate and final uses for each commodity is equal to its gross output. The use table is balanced with a bi-proportional scaling procedure that sequentially adjusts the rows and columns to meet these two conditions and other predetermined controls, including NIPA final expenditure category values including total GDP, industry compensation, and commodity and industry gross output totals from the make table. ${ }^{17}$ Intermediate inputs, gross operating surplus, and the commodity composition of final uses are subject to adjustment during the balancing process.

Price-adjusted measures of GDP by industry are prepared using double deflation using a Fisherideal index number formula, which allows gross output and intermediate inputs to be deflated separately and real value added computed as the residual. Price and quantity indexes for gross output by industry are derived by deflating the commodities produced by an industry as part of its gross output. Price and quantity indexes for intermediate inputs are derived by deflating the commodities that are consumed by an industry as intermediate inputs. The domestic and

\footnotetext{
${ }^{17}$ The use table balancing incorporates over 350 final expenditure category "controls" as published in the NIPAs.
} 
imported portions of intermediate inputs are deflated separately to account for the commodities purchased as inputs from domestic and from foreign sources. ${ }^{18}$ Intermediate inputs at a detailed product level are disaggregated to obtain the domestic and imported portions of intermediate inputs included in each KLEMS input-cost category. For each detailed commodity used by an industry, the portion attributable to imports is calculated as the economy-wide ratio of commodity imports to the total domestic supply of the commodity. ${ }^{19}$ Real value added is computed as the difference between real output and real intermediate inputs within a Fisher-ideal index-number formula.

\section{Estimation Methods - Capital Input}

Capital inputs for the MFP measures are computed in accordance with a service flow concept for physical capital assets-equipment, structures, inventories, and land. Capital inputs for major sectors are determined in three main steps: 1) A very detailed array of capital stocks is developed for various asset types in various industries; 2) asset-type capital stocks are aggregated for each industry to measure capital input for the industry; and 3) industry capital inputs are aggregated to measure sectoral level capital input.

Financial assets are excluded from capital services measures. The aggregate capital services measures are obtained by Tornqvist aggregation of the capital stocks for each asset type within each of 65 NAICS industry groupings using estimated rental prices for each asset type. Each rental price reflects the nominal rate of return to all assets within the industry and rates of economic depreciation and revaluation for the specific asset; rental prices are adjusted for the effects of taxes. Current-dollar capital costs can be defined as each asset's rental price multiplied by its constant-dollar stock, adjusting for capital composition effects.

\footnotetext{
${ }^{18}$ Intermediate inputs at a detailed product level are disaggregated to obtain the domestic and imported portions of intermediate inputs included in each KLEMS category using the so-called import comparability, or proportionality, assumption. For each detailed commodity used by an industry, the portion attributable to imports is calculated as the economy-wide ratio of commodity imports to the total domestic supply of the commodity. ${ }^{19}$ For example, if imports represent 35 percent of the domestic supply of semiconductors, then the estimates in the import-use table assume that imports comprise 35 percent of the value of semiconductors in each industry that uses semiconductors.
} 


\section{Asset Detail}

The asset detail consists of 86 asset types for fixed business equipment and software, structures, inventories, and land. BLS measures of capital stocks for equipment and structures are prepared using NIPA data on real gross investment. Real stocks are constructed as vintage aggregates of historical investments (in real terms) in accordance with an "efficiency" or service flow concept (as distinct from a price or value concept). The efficiency of each asset is assumed to deteriorate only gradually during the early years of an asset's service life and then more quickly in its later life. These "age/efficiency" schedules are based, to the extent possible, on empirical evidence of capital deterioration. Inventory stocks are developed using data from the NIPA and IRS. BLS measures farm and nonfarm nonmanufacturing final inventories and manufacturing inventories by stage of processing: finished goods, work in process, and materials and supplies. Farm land input is based on data from the Economic Research Service of the U.S. Department of Agriculture. A benchmark for nonfarm land is estimated by applying a land-structure ratio based on unpublished estimates by the BLS to the value of structures.

Among equipment, BLS provides additional detail on information processing equipment and software (IPES). IPES is composed of four broad classes of assets: computers and related equipment, software, communications equipment, and other IPES equipment. Computers and related equipment includes mainframe computers, personal computers, printers, terminals, tape drives, storage devices, and integrated systems. Software is comprised of pre-packaged, custom, and own-account software. Communications equipment is not further differentiated. Other IPES includes medical equipment and related instruments, electromedical instruments, nonmedical instruments, photocopying and related equipment, and office and accounting machinery. Structures include nonresidential structures and residential capital that are rented out by profit-making firms or persons.

\section{Capital Stocks}

A central concept in the production of BLS capital measures is that of the "productive" capital stock, or the stock measured in efficiency units. Conceptually, the productive stock represents the amount of new investment required to produce the same capital services actually produced 
by existing assets of all vintages. Thus, total current services from assets of all vintages are proportional to the productive stock. It is this measure of capital stock that is directly associated with productivity. The measurement of the productive stock involves vintage aggregation, which requires historical data on real investment and an "age/efficiency" function that describes the pattern of services that capital goods supply as they age.

BLS computes each type of stock by the perpetual inventory method. The stock at the end of a period is equal to a weighted sum of all past investment, where the weights are the asset's efficiency (defined below) as of a given age.

Mathematically, the productive stock $\mathrm{K}_{\mathrm{t}}$, at the end of the period $\mathrm{t}$ is given by:

$$
\mathrm{K}_{\mathrm{t}}=\sum_{\tau=\mathrm{t}}^{\infty} \mathrm{S}_{\tau-\mathrm{t}} \mathrm{I}_{2 \mathrm{t}-\tau}
$$

where $\mathrm{I}_{\mathrm{t}}$ is investment in period $\mathrm{t}$ and $\mathrm{s}_{\mathrm{t}}$ is the efficiency function.

The efficiency function is a schedule that indicates the quantity of services provided by an asset of a given age, relative to a new asset of the same type. This function is generally assigned a value of 1.00 when the asset is new and declines as the asset ages, eventually approaching or reaching zero. Consequently, investments in the more distant past contribute less to current output.

The mathematical form BLS uses for the age/efficiency relationship is the hyperbolic function:

$$
\begin{array}{lc}
\mathrm{S}_{\mathrm{t}}=\frac{(L-t)}{\left(L-\beta_{t}\right)} & \text { where } 0<\mathrm{t}<\mathrm{L} \\
\mathrm{S}_{\mathrm{t}}=0 & \mathrm{t}>\mathrm{L}
\end{array}
$$

where $s_{t}$ is the relative efficiency of a t-year-old asset

$L$ is the service life

$t$ is the age of the asset

$\beta$ is the parameter allowing the shape of the curve to vary.

BLS uses an efficiency function that declines initially at one-half the straight-line depreciation rate for equipment $(\beta=0.5)$ and at one-fourth the straight-line rate for structures $(\beta=0.75)$. 


\section{Rental Prices}

The "implicit rental price" of capital is based on the neoclassical principle that inputs should be aggregated using weights that reflect their marginal products. The assumption used to formulate the rental price expression is that the purchase price of a capital asset equals the discounted value of the stream of services (and, hence, implicitly the rents) that the asset will provide.

Rental prices are calculated for each asset as

$$
\mathrm{C}_{\mathrm{t}}=\left(\frac{\left(1-u_{t} z_{t}-\mathrm{e}_{t}\right)\left(\mathrm{p}_{t} r_{t}+\mathrm{p}_{t} \mathrm{~d}_{t}-\Delta \mathrm{p}_{t}\right)}{\left(1-\mathrm{u}_{t}\right)}\right)+\mathrm{p}_{\mathrm{t}} \mathrm{x}_{\mathrm{t}}
$$

where

$\mathrm{u}_{\mathrm{t}}$ is the corporate income tax rate

$z_{t}$ is the present value of $\$ 1$ of tax depreciation allowances

$e_{t}$ is the effective rate of the investment tax credit

$r_{t}$ is the nominal rate of return on capital

$d_{t}$ is the average rate of economic depreciation

$p_{t}$ is the deflator for new capital goods

$\Delta p_{t}$ is the revaluation of assets due to inflation in new goods prices

$x_{t}$ is the rate of property taxation on wealth

The following equation is used to derive the implicit internal rate of return, $r_{t}$, by substituting $c_{t}$ from the above equation in the product $c_{t} K_{t}$ :

$$
r_{t}=\left(\frac{\frac{\mathrm{Y}_{t}-\mathrm{K}_{t} \mathrm{p}_{t} \mathrm{x}_{t}-\mathrm{K}_{t}\left(\mathrm{p}_{t} \mathrm{~d}_{t}-\Delta \mathrm{p}_{t}\right)\left(1-\mathrm{u}_{t} \mathrm{z}_{t}-\mathrm{e}_{t}\right)}{\left(1-\mathrm{u}_{t}\right)}}{\frac{\left(\mathrm{K}_{t} \mathrm{p}_{t}\left(1-\mathrm{u}_{t} \mathrm{z}_{t}-\mathrm{e}_{t}\right)\right.}{\left(1-\mathrm{u}_{t}\right)}}\right)
$$

where

$Y_{t}$ is capital income

$\mathrm{K}_{\mathrm{t}}$ is productive capital stock.

After determining the internal rate of return in each industry, rental prices are computed separately for each type of asset within each industry. 


\section{Government, Non-Profit, and Owner-Occupied Capital}

For the purposes of the industry production account, BLS prepared capital measures that are conceptually consistent with the total economy production accounts as described in Harper, Moulton, Rosenthal, and Wasshausen, 2009. These measures are not consistent with BLS major sector published measures, which exclude government, household and non-profit institutions, and owner-occupied housing capital .

For the industry production account, the addition of government, household and non-profit institutions, and owner-occupied housing capital measures require detailed capital stock for each so that a rental price can be calculated. Industry-specific rates of return are used in generating rental prices for non-profit and owner-occupied housing. For government (Federal, State, and Local), rental prices are based on a weighted average of the rates of return and capital gains for the private business industries to calculate capital income, capital stock, and capital input. A detailed breakdown of capital data for the government stock, owner-occupied housing, and non-profits was collected from the BEA NIPA tables in order to generate rental prices on those assets.

Estimation Methods - Labor Input

\section{Labor Hours}

The labor hours reflect annual hours worked. Hours are measured separately for different categories of workers in each industry and are then summed. Hours for each industry and class of worker are calculated as the product of employment, average weekly hours, and 52 weeks per year. They are also adjusted to reflect hours at work. The measures generally reflect the data and methods underlying the hours used in the BLS industry productivity and cost measures, but have been adjusted where necessary to improve consistency with the BEA industry accounts. Hours for NIPA industries were aggregated from estimates for more detailed industries.

The primary source of hours and employment data is the BLS Current Employment Statistics (CES) program. The CES data are based on payroll records from a sample of establishments in 
which the probability of sample selection is related to the establishment size. Data on employment and hours are collected monthly; the reference period for these data is the payroll period including the 12th of the month. Jobs rather than persons are counted in the CES, so that multiple jobholders are counted more than once. Average weekly hours for production and nonsupervisory workers are obtained directly from the CES, while those for nonproduction and supervisory workers are derived using data from the Current Population Survey (CPS) in conjunction with the CES data. ${ }^{20}$

To adjust from hours paid to hours worked, ratios of hours at work to hours-paid, developed from information on employer leave practices in the BLS National Compensation Survey (NCS), are used to adjust the CES paid hours (which includes paid holidays, sick leave and vacation time) to an hours-worked basis. The BLS Hours at Work Survey provided the ratios for years prior to 2000.

To include the self-employed, data from the Current Population Survey (CPS) are used to estimate the number of self-employed workers (partners and proprietors) and their hours. The CPS, a monthly survey of households, counts persons employed, not jobs. Information about primary and secondary jobs for each person is identified and processed separately in order to accurately assign employment and hours estimates to the proper industry and worker category. CPS-based hours of the self-employed reflect hours worked.

To include employment and hours in other sectors not covered by CES data, other source data are used. Estimates of employment and hours for industries in the farm sector are based on data from the U.S. Department of Agriculture. Measures for industries in the nonfarm agriculture sector are based primarily on data from the CPS, together with data from the BLS Quarterly Census of Employment and Wages (QCEW). For mining industries, estimates of nonproduction worker hours are derived from data collected by the Mine Safety and Health Administration. Employment data for the postal service industry are from the CES survey, but estimates of hours for this industry are from the U.S. Postal Service.

\footnotetext{
20 "Construction of Average Weekly Hours for Supervisory and Nonproduction Wage and Salary Workers in Detailed Industries", available at http://www.bls.gov/lpc/iprswawhtechnote.pdf.
} 
Labor Composition

Accounting for labor composition - that is, adjusting labor input of total hours by industry to reflect differences in time and skill-has become an important component of productivity measurement. The importance of this work has been described by Jorgenson, Gollop, and Fraumeni (1987), and by BLS (1993), among others. Just as a key component of including heterogeneous types of assets for capital allows for the measurement of not just the increases in investment, but also the shift in investment to asset types with a higher marginal product; similarly, including a labor input measure that captures demographic characteristic improves the MFP measure by not just capturing an increase in hours worked, but also industry shifts toward higher-skilled workers.

Consequently, we have incorporated labor composition indexes in the quantity measures of labor input in this prototype, integrated account. These measures account for the heterogeneity of the workforce across sex, employment class, age, and education. This approach in measuring labor input is currently used by BLS in official nonfarm business productivity, and is being investigated at the industry level.

A labor composition index was generated using the comprehensive set of hours' measures from BLS and labor matrices of demographic characteristics provided by Dale Jorgenson Associates (DJA) consistent with data used in Jorgenson, Ho, and Samuels (2012). The 192 unique demographic categories are divided by gender, class of worker, age (8 categories), and education (6 categories).

Using the DJA labor matrices, a set of compensation shares were generated for payrolled workers. These shares were multiplied by the published BEA labor compensation figures to produce a 63 industry set of 96 unique demographic categories of compensation for payrolled workers. Similarly, a set of hours' shares were generated and applied to the BLS payrolled worker hours to allocate payrolled hours by industry by 96 demographic categories. ${ }^{21}$ The

\footnotetext{
${ }^{21}$ While detailed data exist for self-employed income from the National Accounts, a labor compensation measure for the self-employed does not exist mainly for reasons of conceptual problems. A common assumption in the productivity literature and one adopted by this study is to assume that the payrolled compensation per hour is the
} 
payrolled compensation data are consistent with published BEA data and the self-employed compensation estimates are based on the assumption that payrolled employees of a given demographic characteristic will receive similar compensation per hour of work as the selfemployed workers.

\section{CONCEPTUAL AND MEASURMENT CHALLENGES}

While this prototype industry-level production account represents an important step in integrating the national accounts with MFP statistics, concerns and challenges remain. Differences arise in part because of the different goals of each agency. BEA's mission is to promote a better understanding of the U.S. economy by providing the most timely, relevant, and accurate economic accounts, which has led to the development of a set of accounts that provides complete and consistent coverage of the domestic output of the entire economy. The BLS mission has been to provide maximum reliability in its productivity measures using economic concepts and methods that are most appropriate for measuring productivity, and to ensure consistency between its official labor productivity series and multifactor productivity series. As a result, some of the data presented here reflect differences in concepts and coverage from the official BLS productivity data. Some challenges remain, including:

The use of a gross output concept for measuring multifactor productivity in the production accounts contrasts with the sectoral industry output approach used in the official productivity measures produced by BLS. BLS adjusts output and intermediate inputs to exclude the doublecounting that occurs when sales between firms in the same industry or sector are included. Double counting occurs both in the output measure and in the purchased intermediates used to produce that output, and therefore is added identically to both the numerator and denominator of the productivity ratio. Inputs of materials produced and consumed in the same sector are already represented by the inputs used to make them. Counting both the intrasector transaction and the inputs that they embody gives an overstated importance to these

same as the self-employed compensation per hour. BEA adjusted this assumption in two cases where anecdotal evidence suggested that this assumption may not be valid and the results from the model suggested a change, those two industries were NAICS 624 -Social Assistance and NAICS Performing arts, spectator sports, museums, and related activities. 
inputs relative to other inputs. Additionally, adding the same transactions to both the numerator and denominator of the productivity equation causes productivity change to be dampened. Further complications arise when the degree of integration within industries changes over time. If a reporting establishment is later split into two establishments for reporting purposes, or if two establishments are later combined into a single facility, this can bias the productivity data over time. Use of sectoral output and input measures avoids these problems.

The production accounts and MFP measures presented here reflect output consistent with GDP for the total economy. These accounts are in keeping with the BEA goal to measure total domestic production. Official BLS productivity measures exclude certain activities because reliable data are lacking to construct output estimates independently of input costs. Estimates for real gross products of general government, private households, and nonprofit institutions, are largely based on labor compensation. Owner-occupied housing and rental value of nonprofit equipment and buildings have no adequate measures for corresponding labor inputs. Government enterprises are excluded because subsidies account for a substantial portion of capital income. Therefore there is no adequate measure of government enterprise capital income in GDP.

Because of these issues, BLS constructs private business and private nonfarm business MFP measures that exclude from GDP general government, government enterprises, private households, nonprofit institutions, and the rental value of owner occupied dwellings. The private business sector accounted for approximately 74 percent of gross domestic product in 2010. In the more aggregate sectors, private business and private nonfarm business, the delivery of goods to final users closely corresponds to value added output. In these measures, output, consisting of only goods and services sold to final consumers, is measured net of price changes and inter-industry transactions and the input measure is an aggregate of labor input and capital service flows.

For its total economy production account measures, BLS replaces the capital consumption allowances that are included in GDP with its own measures of nominal capital services of 
government and nonprofit assets, therefore altering GDP to account for a more complete estimate of capital services input. This adjustment to GDP is based on recommendations in the Harper, Moulton, Rosenthal, and Wasshausen (2008) paper on BLS-BEA integrated GDPproductivity accounts.

This prototype confirms a long-standing challenge related to the presence of negative MFP growth within the non-manufacturing sector, implying the likelihood that some mismeasurement of outputs and/or inputs remains. ${ }^{22}$ Long-term declining productivity in such industries as construction, management of companies, rental and leasing services, legal services and other services is counter-intuitive and raises questions about the accuracy of the data. Challenges remain in accurately measuring the output of many industries. These results suggest further work by BEA and BLS to reconcile output differences, as well as work with the U.S. Census Bureau to continue to improve services-sector measurement, including the expansion of business expense data reported on the annual business expenses and services annual surveys which would be used to improve the measurement of intermediate inputs by industry.

For many of the industries presented here the MFP trends are similar to those published by $B L S$, but for some industries these trends differ. Reconciling the reasons for these differences will be part of the ongoing collaborative work of the two agencies.

\section{CONCLUSION AND POSSIBLE NEXT STEPS}

This paper provides an important down-payment on an integrated, industry-level production account for the United States. It builds on a long-standing history of collaboration between BEA and BLS and illustrates the importance of understanding the sources of economic growth, including KLEMS inputs and MFP growth, within an integrated National Economic Accounts framework, as first described by Jorgenson and Landefeld (2006).

However, much work remains before a BEA/BLS industry-level production account will be released on a regular basis. Challenges to a regular release include an increasingly tough U.S.

\footnotetext{
${ }^{22}$ Harper, Khandrika, Kinoshita, and Rosenthal (2010) provide a clear exposition of both the so-called "productivity paradox" of negative multifactor productivity growth as well as some of the improvements that have occurred in services sector measurement.
} 
budgetary resource environment for introducing new initiatives in addition to methodology considerations seeking resolution in future work.

This prototype was prepared absent any new resources at BEA or BLS, which poses a practical challenge for continuing this initiative in future years. Within BEA, there are many near-term initiatives to improve the accuracy, relevance, and timeliness of its National and Industry Accounts. For example, Strassner and Wasshausen (2011) recently described BEA's work on a fiscal year 2013 budget initiative to produce U.S. quarterly GDP by industry on a near "realtime" basis, which currently is also unfunded. Within BLS, resource constraints and other important initiatives pose a challenge to expanding work in the productivity program. For example, BLS is also working on developing a prototype for calculating quarterly MFP.

Further work to incorporate a labor composition adjustment at the industry level remains a research item on both the BEA and BLS' research agenda. This project makes use of the DJA labor matrices used in similar studies such as that by Jorgenson, Ho, and Samuels (2012). The illustrative adjustments incorporated into this account are based on a good approximation, but further work remains in this area. BLS is close to finalizing a methodology to incorporate industry labor composition measures into its official major sector manufacturing and NIPA-level industry MFP measures.

This initiative to produce an integrated, industry-level production account, despite budgetary considerations, remains one of the BEA's flagship projects (Moyer 2009). Toward this goal, BEA has been working to produce an internally consistent industry-level production account, consistent with GDP, that incorporates capital measures based on a set of assumptions that are consistent with BEA's fixed assets account. Using the assumption that the age-efficiency profile is defined by a constant geometric rate along with similar tax factors as was used in the BLS measure, an alternate capital measure was computed and below is an illustrative example of some of the results that were generated. The age-efficiency assumption implies a geometric pattern in the acquisition price of capital goods as well as a geometric rate of economic depreciation, which is consistent with BEA measures of private investment in equipment and 
software in the NIPAs and in the Fixed Assets account. Since the age-price profile is geometric, the age efficiency profile must also follow the same geometric pattern. ${ }^{23}$

\begin{tabular}{l|r|r|r|r|rr|rr|r|r}
\hline \multirow{2}{*}{ Description } & \multicolumn{2}{|c|}{$1998-2010$} & \multicolumn{2}{|c|}{$2000-2007$} & \multicolumn{2}{c|}{$2007-2010$} & \multicolumn{3}{c}{$2009-2010$} \\
\cline { 2 - 9 } & \multicolumn{2}{|c|}{ BEA } & BLS & BEA & BLS & BEA & BLS & BEA & BLS \\
\hline Apparel and leather and allied products & -2.1 & -2.2 & -2.4 & -2.8 & -5.0 & -3.9 & -5.9 & -3.8 \\
Furniture and related products & 1.1 & 1.4 & 1.6 & 1.5 & -3.9 & -2.3 & -4.3 & -3.3 \\
Miscellaneous professional, scientific, and technical & 9.0 & 8.4 & 8.8 & 8.6 & 3.9 & 3.8 & 3.1 & 2.7 \\
\hline
\end{tabular}

Results are present for two manufacturing industries and one service sector industry where the rates of capital input growth are similar. Despite the differing assumptions with respect to the capital input model, the two measures are remarkably similar in the time periods evaluated. Since official BLS statistics are available through 2010 and the underlying NIPA data are also available through 2010, growth rates incorporate one extra year of data in this comparison. The MFP produced likely would have yielded similar results as well since the capital input measures would not have differed by much.

${ }^{23}$ Jorgenson, Ho, Stiroh (2005) page 152. 


\section{REFERENCES AND BIBLIOGRAPHY}

Baldwin, John R., Tarek M. Harchaoui, "The Integration of the Canadian Productivity Accounts Within The System of National Accounts: Current Status And Challenges Ahead," 2005, NBER Working Paper 11107, February JEL No. C67, E22, 047.

Bureau of Labor Statistics. June 26, 2012. "Multifactor Productivity rends in Manufacturing, 2010." www.bls.gov/news.release/pdf/prod5.pdf.

Bureau of Labor Statistics 1993. Labor Composition and U.S. Productivity Growth, 1948-1990, U.S. Government Printing Office.

Dean, Edwin, and Michael Harper, 2001. "The BLS Productivity Measurement Program," in Charles R. Hulton, Edwin R. Dean and Michael J. Harper, New Developments in Productivity Analysis. University of Chicago Press, 55-84.

Diewert, Erwin W. "Exact and Superlative Index Numbers," 1976. Journal of Econometrics 4, North Holland Publishing Company, 115-145.

Diewert, Erwin W. Revised 2007. "Measuring Productivity in the System of National Accounts," Discussion Paper Number DP07-06, The University of British Columbia.

Fraumeni, Barbara M., Michael J. Harper, Susan G. Powers, and Robert E. Yuskavage. 2006. "An Integrated BEA/BLS Production Account: A First Step and Theoretical Considerations." In Dale W. Jorgenson, J. Steven Landefeld, and William D. Nordhaus, eds., A New Architecture for the U.S. National Accounts. University of Chicago Press, 355-438

Gilmore, Teresa L., Amanda S. Lyndaker, Sarah J. Pack, and Simon N. Randrianrarivelo. 2011. "Annual Industry Accounts: Revised Statistics for 2003-2010," Survey of Current Business 91(December): 15-27.

Harper, Michael, Bhavani Khandrika, Randal Kinoshita, and Steven Rosenthal. 2010. "Nonmanufacturing industry contributions to multifactor productivity, 1987-2006," Monthly Labor Review 133 (June) 16-31.

Harper, Michael, Brent Moulton, Steven Rosenthal, and Dave Wasshausen, 2009. "Integrated GDP-Productivity Accounts." American Economic Review 99(2): 74-79.

Jorgenson, Dale W., Frank Gollop, Barbara Fraumeni, Producivity and U.S. Economic Growth. 1987. Harvard University Press.

Jorgenson, D.W., and Z. Griliches. 1967. "The Explanation of Productivity Change." Review of Economic Studies (July): 249-283.

Jorgenson, Dale W., Mun S. Ho, Jon Samuels, 2012. “A Prototype Industry-Level Production Account for the United States, 1947-2010" Paper for the $2^{\text {nd }}$ World KLEMS Conference, Harvard University, August 9-10, 2012.

Jorgenson, Dale W., Mun S. Ho, Jon Samuels, 2010. "New Data on U.S. Productivity Growth By Industry," Paper for World KLEMS Conference, Harvard University, August 19-20, 2010 
Jorgenson, Dale W., Mun S. Ho, Kevin Stiroh, 2005. Productivity, Information Technology and the American Growth Resurgence, Volume 3.

Jorgenson, Dale W. and J. Steven Landefeld. 2006. "Blueprint for Expanded and Integrated U.S. Accounts: Review, Assessment, and Next Steps." In Dale W. Jorgenson, J. Steven Landefeld, and William D. Nordhaus eds., A New Architecture for the U.S. National Accounts. University of Chicago Press, 13-112.

Lawson, Ann M., Brian C. Moyer, Sumiye Okubo, and Mark A. Planting. 2006. "Integrating Industry and National Economic Accounts: First Steps and Future Improvements." In Dale W. Jorgenson, J. Steven Landefeld, and William D. Nordhaus eds., A New Architecture for the U.S. National Accounts. University of Chicago Press, 215-261.

Mayerhauser, Nicole M. and Erich H. Strassner. 2010. "Preview of the Comprehensive Revision of the Annual Industry Accounts: Changes in Definitions, Classifications, and Statistical Methods." Survey of Current Business 90 (March): 21-34.

Moyer, Brian C. "Future Directions for the Industry Accounts," Survey of Current Business 89 (June): 29-32.

Moyer, Brian C., Mark A. Planting, Mahnaz Fahim-Nader, and Sherlene K.S. Lum. 2004. "Preview of the Comprehensive Revision of the Annual Industry Accounts: Integrating the Annual Input-Output Accounts and the Gross-Domestic-Product-by-Industry Accounts." Survey of Current Business 84(March): 38-51.

National Academy of Sciences. 1979. Measurement and Interpretation of Productivity. National Research Council. Washington, D.C.

Schreyer, Paul. 2001. Productivity Manual: A Guide to the Measurement of Industry-Level and Aggregate Productivity Growth. Paris: Organisation for Economic Co-operation and Development, March.

Solow, Robert M., 1957. Technological Change and the Aggregate Production Function, The Review of Economics and Statistics, Vol. 39 No. 3 August 312-320.

Strassner, Erich H., Gabriel W. Medeiros, and George M. Smith. 2005. "Annual Industry Accounts: Introducing KLEMS Input Estimates for 1997-2003." Survey of Current Business 85(September): 31-65.

Strassner, Erich H. and David B. Wasshausen. "Prototype Quarterly Statistics on U.S. Gross Domestic Product by Industry, 2007-2011." Survey of Current Business 92 (June): 49-65.

OECD. 2001. OECD Productivity Manual: A Guide to the Measurement of Industry-Level and Aggregate Productivity Growth. Paris: Organisation for Economic Cooperation and Development.

U S. Department of Labor Bulletin 2034 "Capital Stock Estimates for Input-Output Industries: Methods and Data," 1979. 


\section{Chart 1}

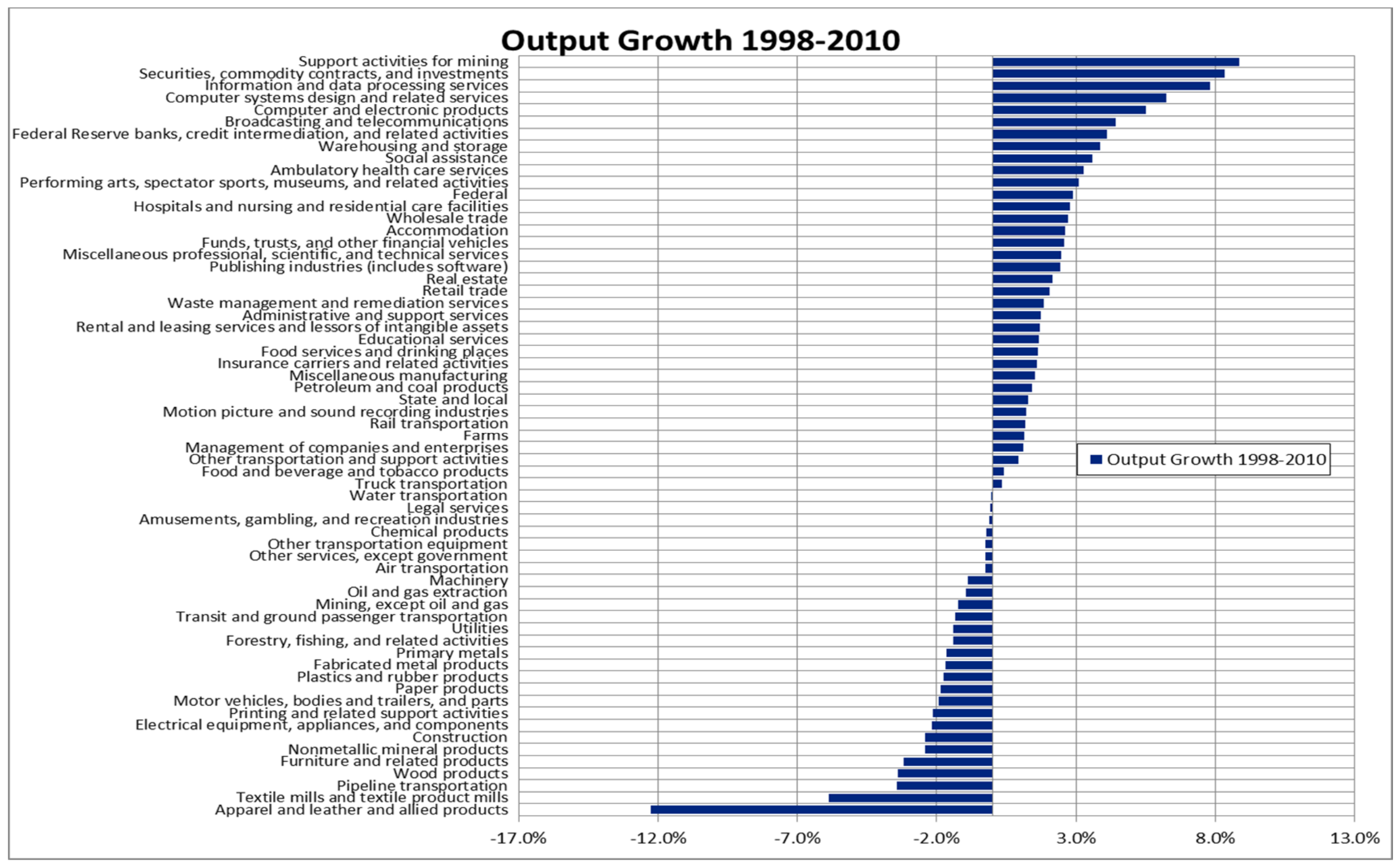




\section{Chart 2}

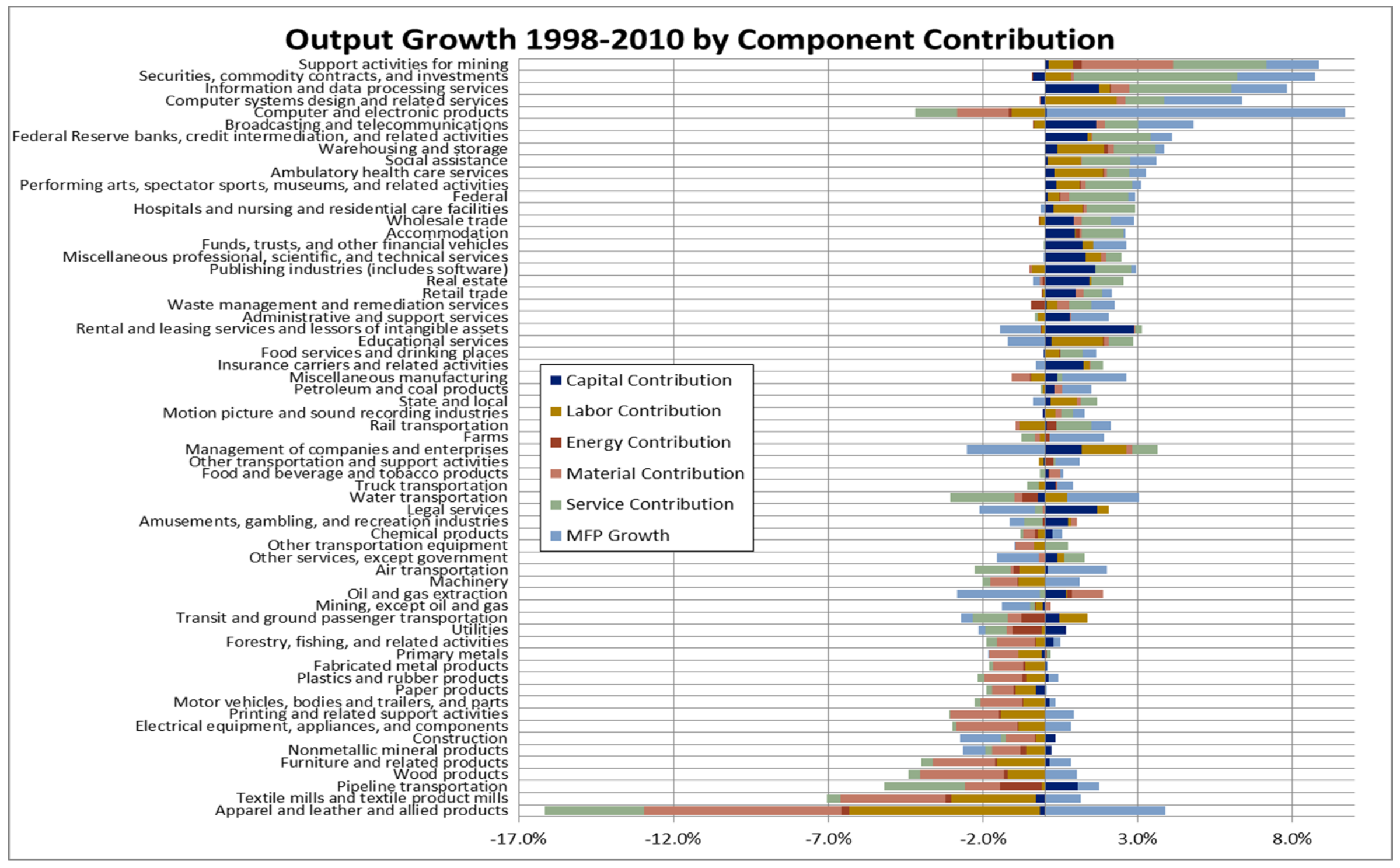




\section{Chart 3}

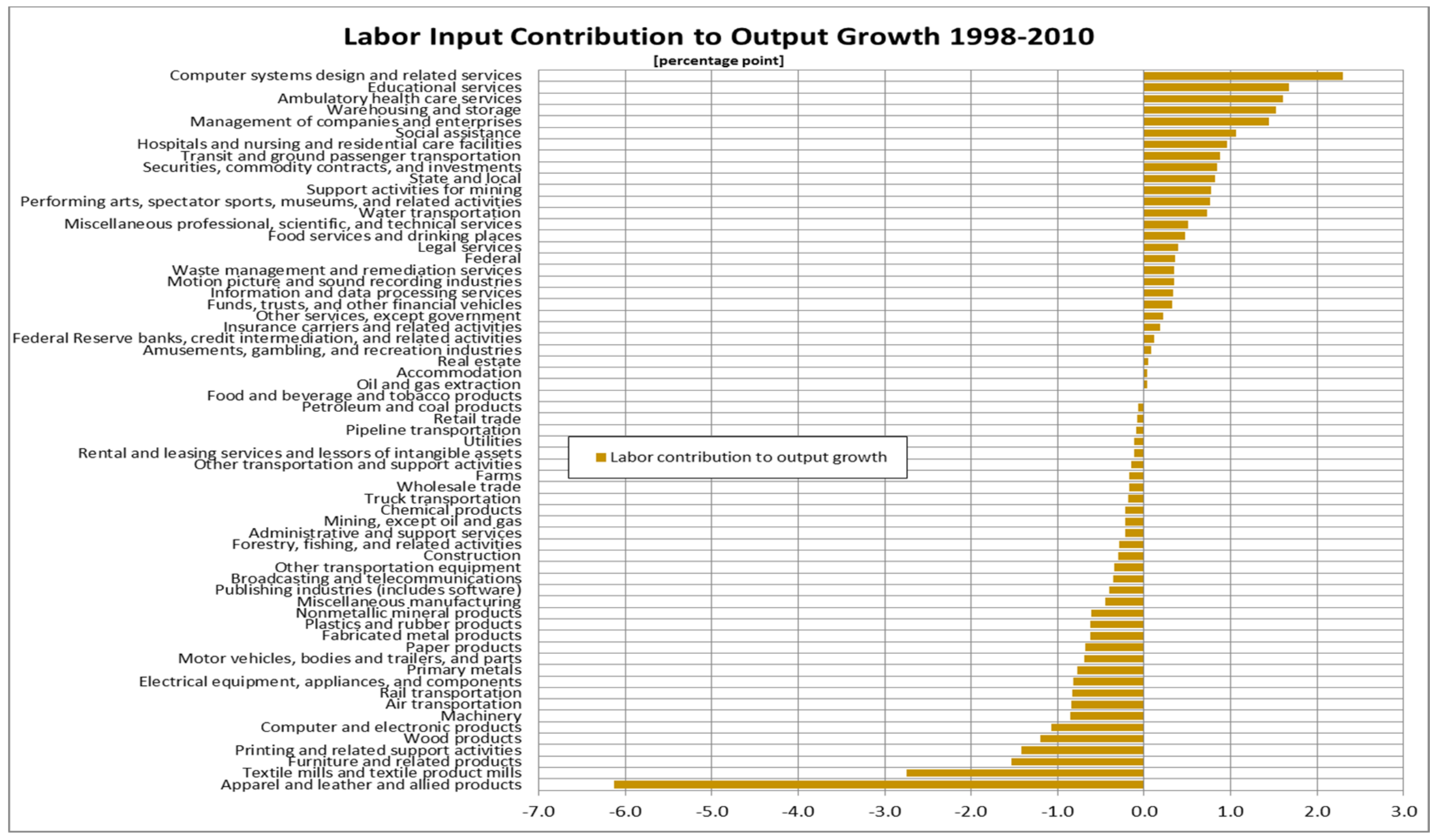




\section{Chart 4}

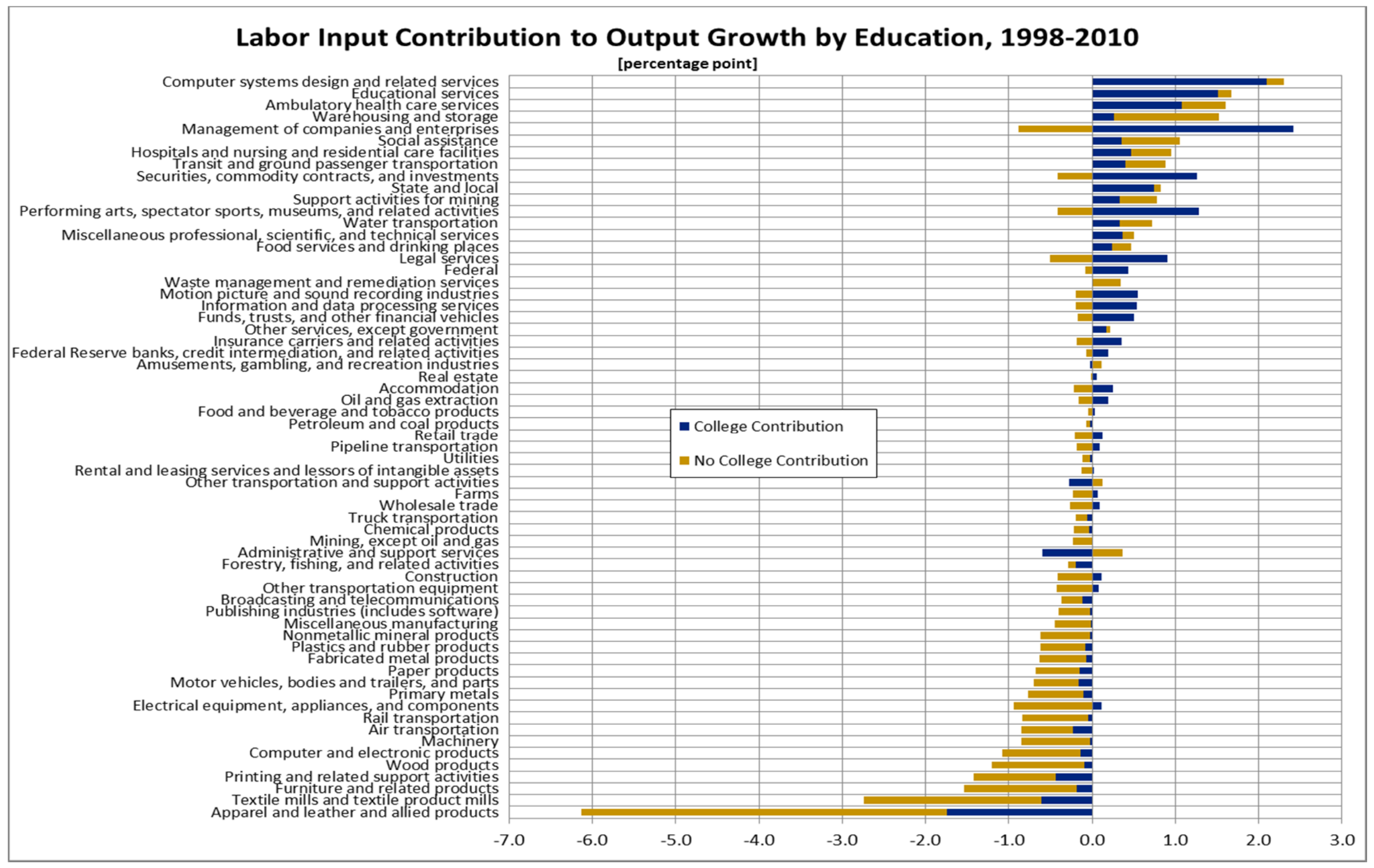




\section{Chart 5}

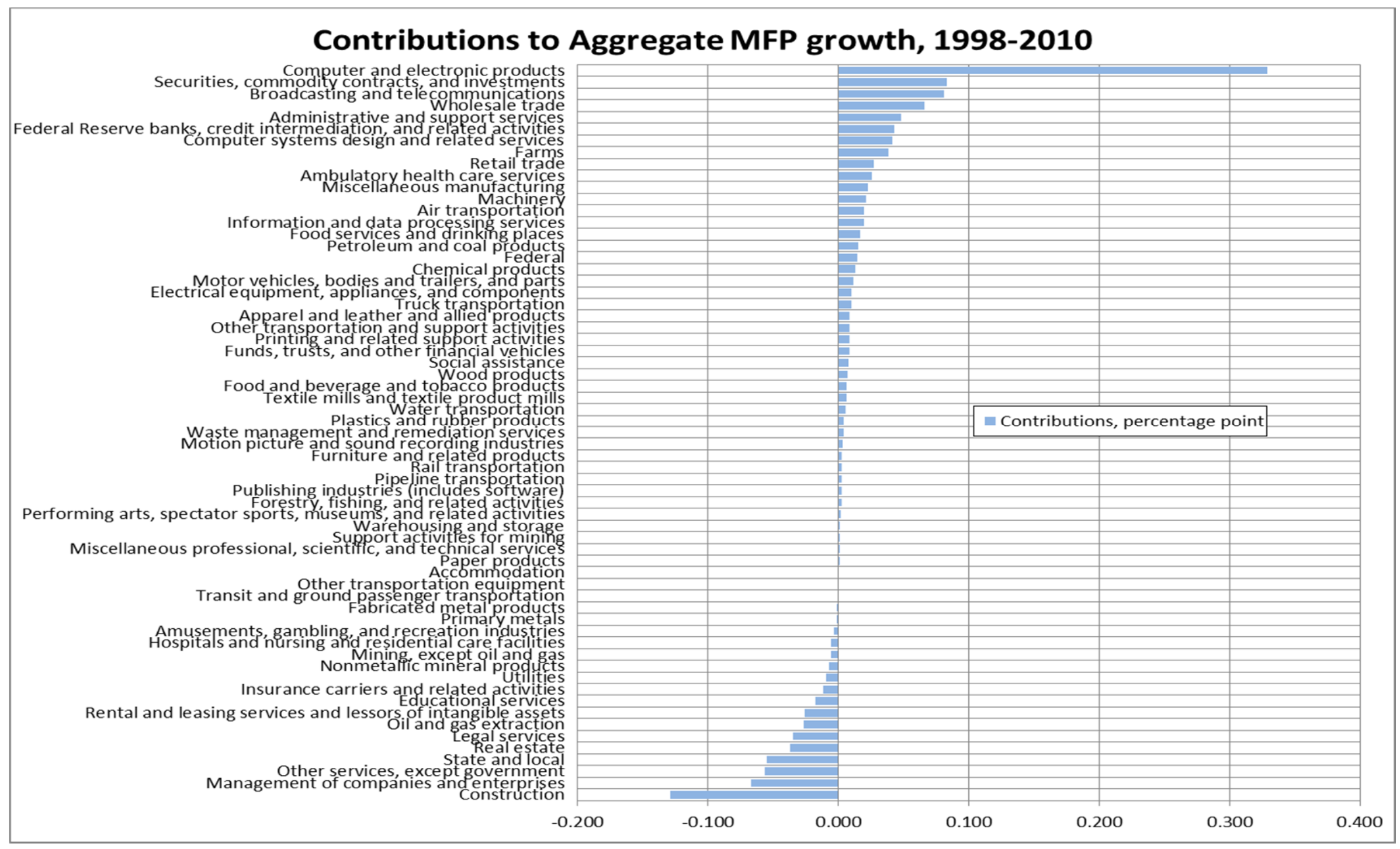


Chart 6

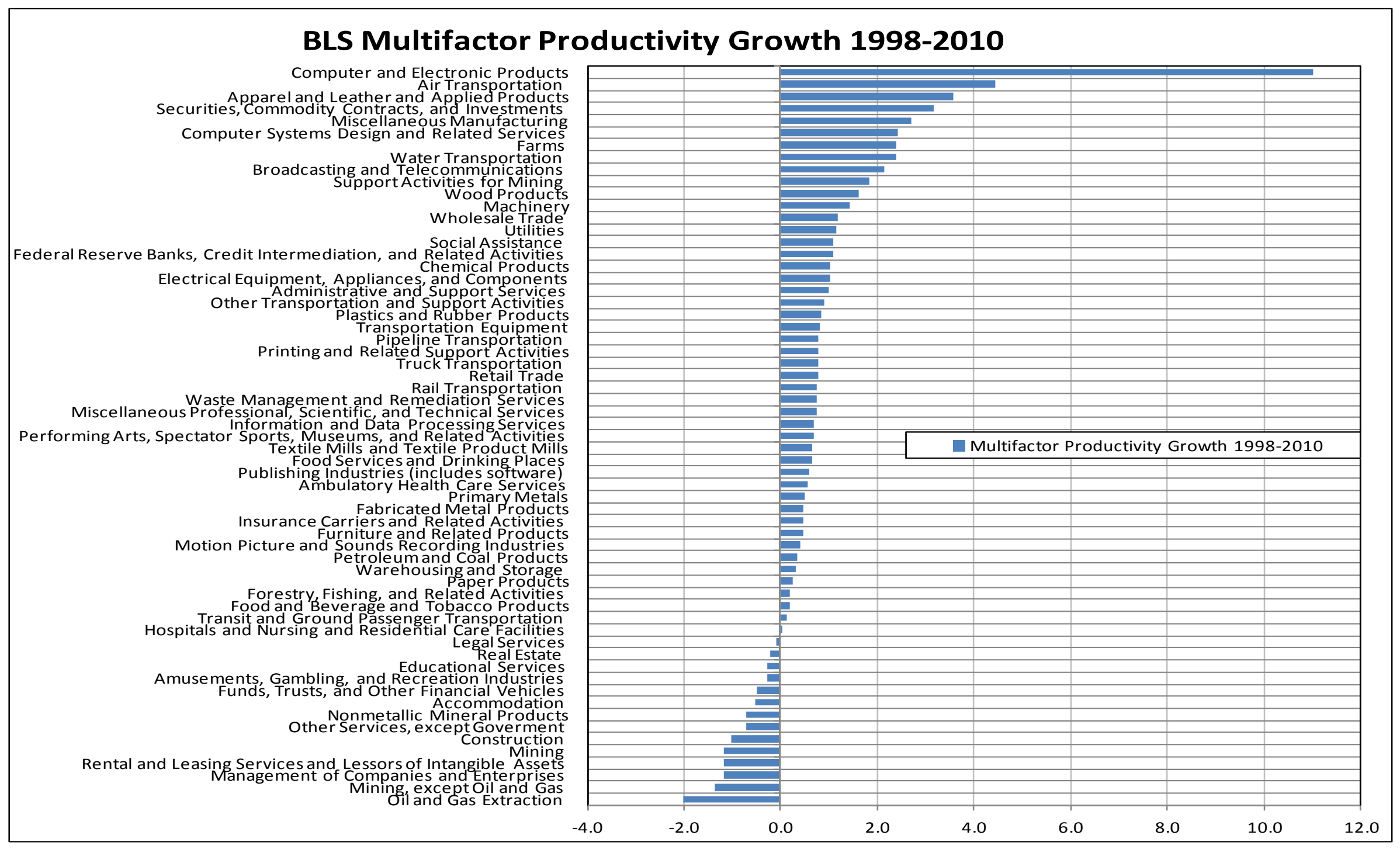




\section{Chart 7}

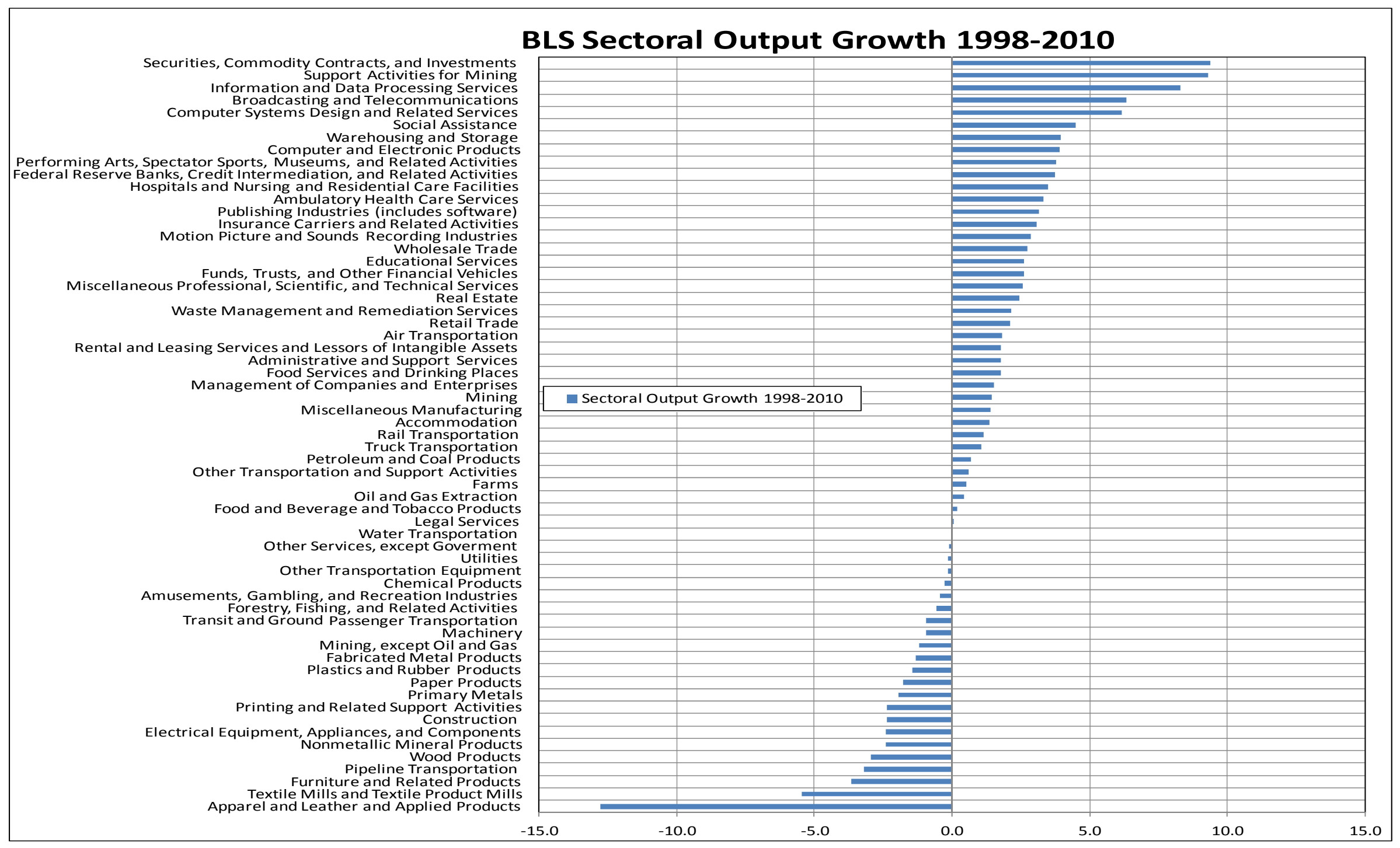


Table 1. Contributions to Aggregate Multifactor Productivity Growth [percentage point]

\begin{tabular}{|c|c|c|c|c|}
\hline Description & $1998-2000$ & $2000-2007$ & 2007-2010 & $1998-2010$ \\
\hline Farms & 0.063 & 0.012 & 0.085 & 0.039 \\
\hline Forestry, fishing, and related activities & 0.008 & 0.008 & -0.014 & 0.002 \\
\hline Oil and gas extraction & -0.123 & -0.015 & 0.010 & -0.027 \\
\hline Mining, except oil and gas & 0.018 & -0.014 & -0.002 & -0.006 \\
\hline Support activities for mining & 0.033 & -0.010 & 0.007 & 0.001 \\
\hline Utilities & 0.111 & -0.023 & -0.061 & -0.010 \\
\hline Construction & -0.059 & -0.210 & 0.014 & -0.129 \\
\hline Food and beverage and tobacco products & 0.021 & 0.018 & -0.029 & 0.006 \\
\hline Textile mills and textile product mills & 0.008 & 0.006 & 0.007 & 0.006 \\
\hline Apparel and leather and allied products & 0.009 & 0.005 & 0.016 & 0.009 \\
\hline Wood products & 0.002 & 0.008 & 0.009 & 0.007 \\
\hline Paper products & 0.005 & 0.006 & -0.015 & 0.000 \\
\hline Printing and related support activities & 0.005 & 0.011 & 0.004 & 0.008 \\
\hline Petroleum and coal products & -0.013 & 0.022 & 0.018 & 0.015 \\
\hline Chemical products & 0.026 & 0.054 & -0.093 & 0.013 \\
\hline Plastics and rubber products & 0.009 & 0.006 & -0.003 & 0.004 \\
\hline Nonmetallic mineral products & -0.015 & -0.006 & -0.005 & -0.007 \\
\hline Primary metals & 0.008 & -0.008 & 0.007 & -0.002 \\
\hline Fabricated metal products & 0.013 & 0.008 & -0.031 & -0.001 \\
\hline Machinery & -0.028 & 0.028 & 0.038 & 0.021 \\
\hline Computer and electronic products & 0.600 & 0.274 & 0.278 & 0.329 \\
\hline Electrical equipment, appliances, and components & 0.037 & 0.007 & -0.003 & 0.010 \\
\hline Motor vehicles, bodies and trailers, and parts & -0.024 & 0.057 & -0.070 & 0.012 \\
\hline Other transportation equipment & 0.023 & 0.014 & -0.050 & -0.001 \\
\hline Furniture and related products & 0.002 & 0.003 & 0.003 & 0.003 \\
\hline Miscellaneous manufacturing & 0.034 & 0.019 & 0.024 & 0.023 \\
\hline Wholesale trade & 0.179 & 0.111 & -0.114 & 0.066 \\
\hline Retail trade & -0.021 & 0.013 & 0.091 & 0.027 \\
\hline Air transportation & 0.031 & 0.031 & -0.013 & 0.020 \\
\hline Rail transportation & 0.015 & 0.001 & -0.002 & 0.003 \\
\hline Water transportation & -0.002 & 0.008 & 0.005 & 0.005 \\
\hline Truck transportation & 0.024 & 0.009 & 0.003 & 0.010 \\
\hline Transit and ground passenger transportation & 0.003 & -0.001 & -0.003 & -0.001 \\
\hline Pipeline transportation & 0.017 & 0.001 & -0.003 & 0.003 \\
\hline Other transportation and support activities & 0.005 & 0.021 & -0.018 & 0.008 \\
\hline Warehousing and storage & -0.006 & 0.003 & 0.003 & 0.001 \\
\hline Publishing industries (includes software) & -0.115 & 0.041 & -0.009 & 0.002 \\
\hline Motion picture and sound recording industries & -0.036 & 0.020 & -0.011 & 0.003 \\
\hline Broadcasting and telecommunications & -0.004 & 0.129 & 0.026 & 0.081 \\
\hline Information and data processing services & -0.094 & 0.057 & 0.007 & 0.019 \\
\hline Federal Reserve banks, credit intermediation, and & 0.020 & -0.006 & 0.171 & 0.043 \\
\hline Securities, commodity contracts, and investments & 0.167 & 0.033 & 0.145 & 0.084 \\
\hline Insurance carriers and related activities & 0.049 & -0.024 & -0.024 & -0.012 \\
\hline Funds, trusts, and other financial vehicles & -0.006 & 0.010 & 0.013 & 0.008 \\
\hline Real estate & 0.193 & -0.018 & -0.235 & -0.037 \\
\hline Rental and leasing services and lessors of intangibl & -0.148 & -0.020 & 0.042 & -0.026 \\
\hline Legal services & 0.004 & -0.041 & -0.045 & -0.035 \\
\hline Miscellaneous professional, scientific, and technic & -0.099 & 0.008 & 0.048 & 0.000 \\
\hline Computer systems design and related services & -0.008 & 0.048 & 0.057 & 0.041 \\
\hline Management of companies and enterprises & -0.008 & -0.068 & -0.104 & -0.067 \\
\hline Administrative and support services & -0.012 & 0.061 & 0.057 & 0.048 \\
\hline Waste management and remediation services & 0.007 & 0.003 & 0.003 & 0.004 \\
\hline Educational services & -0.012 & -0.018 & -0.021 & -0.018 \\
\hline Ambulatory health care services & 0.089 & -0.001 & 0.046 & 0.026 \\
\hline Hospitals and nursing and residential care facilities & -0.018 & -0.016 & 0.027 & -0.005 \\
\hline Social assistance & 0.000 & 0.012 & 0.004 & 0.008 \\
\hline Performing arts, spectator sports, museums, and re & 0.011 & -0.004 & 0.010 & 0.002 \\
\hline Amusements, gambling, and recreation industries & 0.002 & -0.003 & -0.009 & -0.004 \\
\hline Accommodation & -0.001 & 0.008 & -0.019 & 0.000 \\
\hline Food services and drinking places & 0.064 & 0.026 & -0.037 & 0.017 \\
\hline Other services, except government & -0.021 & -0.065 & -0.059 & -0.056 \\
\hline Federal & -0.051 & 0.028 & 0.027 & 0.015 \\
\hline State and local & -0.059 & -0.064 & -0.029 & -0.055 \\
\hline Sum & 0.928 & 0.614 & 0.171 & 0.556 \\
\hline
\end{tabular}




\begin{tabular}{|c|c|c|c|c|}
\hline Description & 1998-2000 & 2000-2007 & $2007-2010$ & $1998-2010$ \\
\hline Farms & 3.0 & 0.6 & 3.7 & 1.8 \\
\hline Forestry, fishing, and related activities & 1.8 & 2.0 & -4.9 & 0.2 \\
\hline Oil and gas extraction & -12.8 & -1.0 & 0.1 & -2.7 \\
\hline Mining, except oil and gas & 3.2 & -2.4 & -0.1 & -0.9 \\
\hline Support activities for mining & 13.2 & -1.3 & 1.0 & 1.7 \\
\hline Utilities & 3.4 & -0.5 & -2.1 & -0.2 \\
\hline Construction & -0.6 & -2.2 & 0.2 & -1.3 \\
\hline Food and beverage and tobacco products & 0.4 & 0.4 & -0.6 & 0.1 \\
\hline Textile mills and textile product mills & 0.8 & 1.0 & 1.8 & 1.2 \\
\hline Apparel and leather and allied products & 1.2 & 1.3 & 11.8 & 3.9 \\
\hline Wood products & 0.2 & 0.9 & 1.7 & 1.0 \\
\hline Paper products & 0.3 & 0.5 & -1.2 & 0.0 \\
\hline Printing and related support activities & 0.5 & 1.2 & 0.6 & 0.9 \\
\hline Petroleum and coal products & -1.0 & 1.6 & 0.6 & 0.9 \\
\hline Chemical products & 0.6 & 1.2 & -1.9 & 0.3 \\
\hline Plastics and rubber products & 0.5 & 0.4 & -0.1 & 0.3 \\
\hline Nonmetallic mineral products & -1.5 & -0.6 & -0.4 & -0.7 \\
\hline Primary metals & 0.4 & -0.3 & 0.3 & 0.0 \\
\hline Fabricated metal products & 0.5 & 0.4 & -1.2 & 0.0 \\
\hline Machinery & -0.9 & 1.3 & 2.0 & 1.1 \\
\hline Computer and electronic products & 12.2 & 8.5 & 10.7 & 9.6 \\
\hline Electrical equipment, appliances, and components & 3.0 & 0.8 & -0.6 & 0.8 \\
\hline Motor vehicles, bodies and trailers, and parts & -0.5 & 1.4 & -2.2 & 0.2 \\
\hline Other transportation equipment & 1.1 & 0.9 & -2.9 & 0.0 \\
\hline Furniture and related products & 0.2 & 0.5 & 1.5 & 0.7 \\
\hline Miscellaneous manufacturing & 2.9 & 1.7 & 2.3 & 2.1 \\
\hline Wholesale trade & 2.0 & 1.3 & -1.4 & 0.8 \\
\hline Retail trade & -0.2 & 0.1 & 1.1 & 0.3 \\
\hline Air transportation & 2.4 & 3.2 & -1.3 & 1.9 \\
\hline Rail transportation & 3.4 & 0.3 & -0.4 & 0.6 \\
\hline Water transportation & -0.6 & 3.3 & 2.0 & 2.3 \\
\hline Truck transportation & 1.2 & 0.4 & 0.3 & 0.5 \\
\hline Transit and ground passenger transportation & 1.0 & -0.3 & -1.4 & -0.4 \\
\hline Pipeline transportation & 6.6 & 0.1 & -2.0 & 0.7 \\
\hline Other transportation and support activities & 0.4 & 2.0 & -1.8 & 0.8 \\
\hline Warehousing and storage & -2.0 & 0.8 & 0.6 & 0.3 \\
\hline Publishing industries (includes software) & -4.5 & 1.7 & -0.4 & 0.2 \\
\hline Motion picture and sound recording industries & -4.7 & 2.6 & -1.5 & 0.4 \\
\hline Broadcasting and telecommunications & -0.1 & 2.8 & 0.6 & 1.8 \\
\hline Information and data processing services & -13.0 & 6.4 & 0.8 & 1.8 \\
\hline Federal Reserve banks, credit intermediation, and re & 0.4 & 0.0 & 2.4 & 0.7 \\
\hline Securities, commodity contracts, and investments & 5.3 & 1.0 & 4.2 & 2.5 \\
\hline Insurance carriers and related activities & 1.1 & -0.6 & -0.4 & -0.3 \\
\hline Funds, trusts, and other financial vehicles & -0.6 & 1.3 & 1.6 & 1.1 \\
\hline Real estate & 1.3 & -0.1 & -1.5 & -0.2 \\
\hline Rental and leasing services and lessors of intangible & -7.4 & -1.1 & 2.2 & -1.3 \\
\hline Legal services & 0.2 & -2.1 & -2.4 & -1.8 \\
\hline Miscellaneous professional, scientific, and technical & -1.6 & 0.1 & 0.7 & 0.0 \\
\hline Computer systems design and related services & -0.5 & 3.1 & 3.2 & 2.5 \\
\hline Management of companies and enterprises & -0.3 & -2.6 & -3.8 & -2.5 \\
\hline Administrative and support services & -0.3 & 1.6 & 1.4 & 1.2 \\
\hline Waste management and remediation services & 1.2 & 0.7 & 0.5 & 0.7 \\
\hline Educational services & -0.9 & -1.3 & -1.3 & -1.2 \\
\hline Ambulatory health care services & 1.9 & 0.0 & 0.9 & 0.5 \\
\hline Hospitals and nursing and residential care facilities & -0.4 & -0.3 & 0.5 & -0.1 \\
\hline Social assistance & 0.1 & 1.2 & 0.4 & 0.8 \\
\hline Performing arts, spectator sports, museums, and rel & 1.5 & -0.4 & 1.0 & 0.3 \\
\hline Amusements, gambling, and recreation industries & 0.2 & -0.3 & -1.4 & -0.5 \\
\hline Accommodation & -0.1 & 0.6 & -1.1 & 0.1 \\
\hline Food services and drinking places & 1.8 & 0.7 & -1.0 & 0.5 \\
\hline Other services, except government & -0.5 & -1.5 & -1.5 & -1.3 \\
\hline Federal & -0.8 & 0.4 & 0.4 & 0.2 \\
\hline State and local & -0.5 & -0.5 & -0.2 & -0.4 \\
\hline
\end{tabular}




\begin{tabular}{|c|c|c|c|c|c|c|c|}
\hline Descrption & Output & Capital & Labor & Energy & Material & Service & MFP \\
\hline Farms & 1.16 & 0.03 & -0.17 & 0.11 & -0.17 & -0.43 & 1.78 \\
\hline Forestry, fishing, and related activities & -1.41 & 0.27 & -0.29 & -0.05 & -1.21 & -0.33 & 0.21 \\
\hline Oil and gas extraction & -0.95 & 0.68 & 0.03 & 0.16 & 1.02 & -0.17 & -2.67 \\
\hline Mining, except oil and gas & -1.21 & -0.08 & -0.22 & -0.03 & 0.18 & -0.14 & -0.93 \\
\hline Support activities for mining & 8.86 & 0.13 & 0.78 & 0.27 & 2.98 & 3.01 & 1.70 \\
\hline Utilities & -1.40 & 0.69 & -0.11 & -0.92 & -0.21 & -0.67 & -0.23 \\
\hline Construction & -2.41 & 0.34 & -0.30 & -0.03 & -0.93 & -0.16 & -1.33 \\
\hline Food and beverage and tobacco products & 0.42 & 0.12 & -0.01 & 0.02 & 0.34 & -0.17 & 0.12 \\
\hline Textile mills and textile product mills & -5.87 & -0.29 & -2.74 & -0.19 & -3.40 & -0.42 & 1.17 \\
\hline Apparel and leather and allied products & -12.26 & -0.18 & -6.14 & -0.26 & -6.39 & -3.20 & 3.89 \\
\hline Wood products & -3.39 & 0.01 & -1.20 & -0.14 & -2.68 & -0.38 & 1.00 \\
\hline Paper products & -1.85 & -0.28 & -0.68 & -0.06 & -0.69 & -0.18 & 0.04 \\
\hline Printing and related support activities & -2.15 & 0.01 & -1.42 & -0.06 & -1.59 & -0.02 & 0.92 \\
\hline Petroleum and coal products & 1.43 & 0.31 & -0.07 & 0.01 & 0.24 & -0.06 & 0.93 \\
\hline Chemical products & -0.23 & 0.23 & -0.22 & -0.11 & -0.39 & -0.07 & 0.33 \\
\hline Plastics and rubber products & -1.76 & 0.11 & -0.62 & -0.12 & -1.21 & -0.23 & 0.31 \\
\hline Nonmetallic mineral products & -2.43 & 0.22 & -0.61 & -0.17 & -0.92 & -0.21 & -0.73 \\
\hline Primary metals & -1.66 & -0.10 & -0.77 & 0.05 & -0.92 & 0.13 & -0.04 \\
\hline Fabricated metal products & -1.70 & 0.07 & -0.63 & -0.08 & -0.95 & -0.12 & 0.03 \\
\hline Machinery & -0.89 & 0.02 & -0.85 & -0.04 & -0.87 & -0.25 & 1.09 \\
\hline Computer and electronic products & 5.52 & 0.05 & -1.08 & -0.11 & -1.65 & -1.35 & 9.64 \\
\hline Electrical equipment, appliances, and component & -2.17 & -0.02 & -0.82 & -0.06 & -1.97 & -0.12 & 0.83 \\
\hline Motor vehicles, bodies and trailers, and parts & -1.94 & 0.14 & -0.70 & -0.02 & -1.36 & -0.18 & 0.18 \\
\hline Other transportation equipment & -0.24 & 0.04 & -0.35 & -0.01 & -0.59 & 0.71 & -0.03 \\
\hline Furniture and related products & -3.17 & 0.15 & -1.53 & -0.08 & -2.02 & -0.38 & 0.69 \\
\hline Miscellaneous manufacturing & 1.54 & 0.40 & -0.45 & -0.03 & -0.60 & 0.17 & 2.05 \\
\hline Wholesale trade & 2.71 & 0.92 & -0.17 & 0.00 & 0.28 & 0.93 & 0.76 \\
\hline Retail trade & 2.05 & 0.99 & -0.08 & -0.03 & 0.27 & 0.59 & 0.31 \\
\hline Air transportation & -0.27 & 0.09 & -0.84 & -0.16 & -0.12 & -1.15 & 1.91 \\
\hline Rail transportation & 1.17 & 0.05 & -0.83 & 0.32 & -0.13 & 1.12 & 0.65 \\
\hline Water transportation & -0.01 & -0.22 & 0.72 & -0.52 & -0.27 & -2.06 & 2.32 \\
\hline Truck transportation & 0.34 & 0.35 & -0.19 & 0.03 & 0.01 & -0.38 & 0.53 \\
\hline Transit and ground passenger transportation & -1.35 & 0.48 & 0.88 & -0.76 & -0.44 & -1.14 & -0.36 \\
\hline Pipeline transportation & -3.44 & 1.05 & -0.09 & -1.37 & -1.12 & -2.60 & 0.70 \\
\hline Other transportation and support activities & 0.92 & -0.05 & -0.15 & 0.28 & 0.00 & 0.06 & 0.80 \\
\hline Warehousing and storage & 3.86 & 0.39 & 1.52 & 0.11 & 0.20 & 1.37 & 0.27 \\
\hline Publishing industries (includes software) & 2.43 & 1.62 & -0.41 & -0.02 & -0.09 & 1.16 & 0.16 \\
\hline Motion picture and sound recording industries & 1.20 & -0.08 & 0.34 & 0.00 & 0.16 & 0.39 & 0.38 \\
\hline Broadcasting and telecommunications & 4.44 & 1.66 & -0.36 & -0.01 & 0.28 & 1.08 & 1.79 \\
\hline Information and data processing services & 7.81 & 1.76 & 0.34 & 0.03 & 0.60 & 3.31 & 1.77 \\
\hline Federal Reserve banks, credit intermediation, and & 4.10 & 1.38 & 0.12 & 0.00 & 0.03 & 1.90 & 0.67 \\
\hline Securities, commodity contracts, and investments & 8.33 & -0.39 & 0.85 & -0.02 & 0.10 & 5.28 & 2.52 \\
\hline Insurance carriers and related activities & 1.59 & 1.24 & 0.18 & 0.00 & 0.05 & 0.41 & -0.29 \\
\hline Funds, trusts, and other financial vehicles & 2.57 & 1.22 & 0.32 & -0.01 & -0.01 & -0.04 & 1.08 \\
\hline Real estate & 2.14 & 1.44 & 0.05 & -0.06 & -0.11 & 1.04 & -0.22 \\
\hline Rental and leasing services and lessors of intangib & 1.69 & 2.89 & -0.11 & -0.02 & 0.00 & 0.24 & -1.31 \\
\hline Legal services & -0.06 & 1.68 & 0.39 & -0.01 & -0.05 & -0.27 & -1.80 \\
\hline Miscellaneous professional, scientific, and technid & 2.47 & 1.32 & 0.51 & -0.01 & 0.14 & 0.53 & 0.00 \\
\hline Computer systems design and related services & 6.23 & -0.13 & 2.30 & -0.01 & 0.28 & 1.26 & 2.52 \\
\hline Management of companies and enterprises & 1.11 & 1.19 & 1.44 & 0.00 & 0.20 & 0.81 & -2.54 \\
\hline Administrative and support services & 1.72 & 0.81 & -0.22 & 0.00 & 0.04 & -0.11 & 1.22 \\
\hline Waste management and remediation services & 1.83 & 0.05 & 0.35 & -0.43 & 0.39 & 0.72 & 0.73 \\
\hline Educational services & 1.65 & 0.21 & 1.67 & 0.03 & 0.16 & 0.77 & -1.19 \\
\hline Ambulatory health care services & 3.27 & 0.29 & 1.60 & 0.00 & 0.11 & 0.73 & 0.53 \\
\hline Hospitals and nursing and residential care facilitie & 2.79 & 0.27 & 0.96 & 0.02 & 0.11 & 1.57 & -0.13 \\
\hline Social assistance & 3.60 & 0.08 & 1.07 & 0.02 & 0.03 & 1.55 & 0.85 \\
\hline Performing arts, spectator sports, museums, and $r$ & 3.09 & 0.37 & 0.77 & 0.03 & 0.15 & 1.51 & 0.26 \\
\hline Amusements, gambling, and recreation industries & -0.10 & 0.76 & 0.08 & -0.09 & 0.20 & -0.59 & -0.46 \\
\hline Accommodation & 2.60 & 0.97 & 0.03 & 0.11 & 0.07 & 1.36 & 0.05 \\
\hline Food services and drinking places & 1.63 & -0.04 & 0.47 & 0.01 & 0.00 & 0.72 & 0.45 \\
\hline Other services, except government & -0.26 & 0.41 & 0.22 & -0.02 & -0.18 & 0.65 & -1.33 \\
\hline Federal & 2.90 & 0.10 & 0.36 & 0.04 & 0.26 & 1.92 & 0.22 \\
\hline State and local & 1.30 & 0.19 & 0.83 & 0.01 & 0.12 & 0.55 & -0.40 \\
\hline
\end{tabular}




\begin{tabular}{|c|c|c|c|}
\hline Description & $\begin{array}{l}\text { College Labor } \\
\text { Contribution }\end{array}$ & $\begin{array}{l}\text { No College Labor } \\
\text { Contribution }\end{array}$ & $\begin{array}{l}\text { Labor Composition } \\
\text { Contribution }\end{array}$ \\
\hline Farms & 0.07 & -0.23 & -0.17 \\
\hline Forestry, fishing, and related activities & -0.19 & -0.09 & -0.29 \\
\hline Oil and gas extraction & 0.20 & -0.16 & 0.03 \\
\hline Mining, except oil and gas & 0.01 & -0.23 & -0.22 \\
\hline Support activities for mining & 0.33 & 0.45 & 0.78 \\
\hline Utilities & -0.02 & -0.09 & -0.11 \\
\hline Construction & 0.12 & -0.42 & -0.30 \\
\hline Food and beverage and tobacco products & 0.03 & -0.04 & -0.01 \\
\hline Textile mills and textile product mills & -0.61 & -2.14 & -2.74 \\
\hline Apparel and leather and allied products & -1.74 & -4.39 & -6.14 \\
\hline Wood products & -0.09 & -1.10 & -1.20 \\
\hline Paper products & -0.15 & -0.53 & -0.68 \\
\hline Printing and related support activities & -0.43 & -0.98 & -1.42 \\
\hline Petroleum and coal products & -0.02 & -0.05 & -0.07 \\
\hline Chemical products & -0.03 & -0.18 & -0.22 \\
\hline Plastics and rubber products & -0.09 & -0.54 & -0.62 \\
\hline Nonmetallic mineral products & -0.03 & -0.59 & -0.61 \\
\hline Primary metals & -0.11 & -0.67 & -0.77 \\
\hline Fabricated metal products & -0.06 & -0.56 & -0.63 \\
\hline Machinery & -0.03 & -0.82 & -0.85 \\
\hline Computer and electronic products & -0.14 & -0.93 & -1.08 \\
\hline Electrical equipment, appliances, and compon & 0.12 & -0.94 & -0.82 \\
\hline Motor vehicles, bodies and trailers, and parts & -0.16 & -0.54 & -0.70 \\
\hline Other transportation equipment & 0.08 & -0.43 & -0.35 \\
\hline Furniture and related products & -0.18 & -1.35 & -1.53 \\
\hline Miscellaneous manufacturing & -0.01 & -0.43 & -0.45 \\
\hline Wholesale trade & 0.09 & -0.26 & -0.17 \\
\hline Retail trade & 0.13 & -0.21 & -0.08 \\
\hline Air transportation & -0.23 & -0.61 & -0.84 \\
\hline Rail transportation & -0.05 & -0.78 & -0.83 \\
\hline Water transportation & 0.33 & 0.39 & 0.72 \\
\hline Truck transportation & -0.05 & -0.14 & -0.19 \\
\hline Transit and ground passenger transportation & 0.40 & 0.48 & 0.88 \\
\hline Pipeline transportation & 0.09 & -0.19 & -0.09 \\
\hline Other transportation and support activities & -0.28 & 0.12 & -0.15 \\
\hline Warehousing and storage & 0.26 & 1.27 & 1.52 \\
\hline Publishing industries (includes software) & -0.03 & -0.38 & -0.41 \\
\hline Motion picture and sound recording industries & 0.55 & -0.20 & 0.34 \\
\hline Broadcasting and telecommunications & -0.12 & -0.24 & -0.36 \\
\hline Information and data processing se vices & 0.53 & -0.19 & 0.34 \\
\hline Federal Reserve banks, credit intermediation, & 0.19 & -0.07 & 0.12 \\
\hline Securities, commodity contracts, and investme & 1.26 & -0.41 & 0.85 \\
\hline Insurance carriers and related activities & 0.36 & -0.18 & 0.18 \\
\hline Funds, trusts, and other financial vehicles & 0.50 & -0.18 & 0.32 \\
\hline Real estate & 0.06 & -0.01 & 0.05 \\
\hline Rental and leasing services and lessors of intar & 0.02 & -0.13 & -0.11 \\
\hline Legal services & 0.90 & -0.50 & 0.39 \\
\hline Miscellaneous professional, scientific, and tec & 0.37 & 0.14 & 0.51 \\
\hline Computer systems design and related services & 2.10 & 0.20 & 2.30 \\
\hline Management of companies and enterprises & 2.42 & -0.88 & 1.44 \\
\hline Administrative and support services & -0.59 & 0.37 & -0.22 \\
\hline Waste management and remediation services & 0.00 & 0.34 & 0.35 \\
\hline Educational senices & 1.52 & 0.16 & 1.67 \\
\hline Ambulatory health care services & 1.07 & 0.53 & 1.60 \\
\hline Hospitals and nursing and residential care facil & 0.47 & 0.48 & 0.96 \\
\hline Social assistance & 0.36 & 0.70 & 1.07 \\
\hline Performingarts, spectator sports, museums, ar & 1.28 & -0.41 & 0.77 \\
\hline Amusements, gambling, and recreation indust & -0.02 & 0.11 & 0.08 \\
\hline Accommodation & 0.26 & -0.22 & 0.03 \\
\hline Food services and drinking places & 0.24 & 0.23 & 0.47 \\
\hline Other services, except government & 0.17 & 0.06 & 0.22 \\
\hline Federal & 0.43 & -0.08 & 0.36 \\
\hline State and local & 0.74 & 0.09 & 0.83 \\
\hline
\end{tabular}




\begin{tabular}{|c|c|c|c|c|}
\hline Description & $\begin{array}{c}2009 \text { Value } \\
\text { Added Share }\end{array}$ & $\begin{array}{l}\text { Domar } \\
\text { Weight }\end{array}$ & MFP Growth & $\begin{array}{c}\text { Contribution } \\
\text { to Aggregate } \\
\text { MFP }\end{array}$ \\
\hline Computer and electronic products & 1.5 & 0.035 & 9.6 & 0.329 \\
\hline Securities, commodity contracts, and investments & 1.2 & 0.033 & 2.5 & 0.084 \\
\hline Broadcasting and telecommunications & 2.4 & 0.047 & 1.8 & 0.081 \\
\hline Wholesale trade & 5.5 & 0.084 & 0.8 & 0.066 \\
\hline Administrative and support services & 2.6 & 0.040 & 1.2 & 0.048 \\
\hline Federal Reserve banks, credit intermediation, and $r$ & 3.8 & 0.064 & 0.7 & 0.043 \\
\hline Computer systems design and related services & 1.2 & 0.016 & 2.5 & 0.041 \\
\hline Farms & 0.8 & 0.021 & 1.8 & 0.039 \\
\hline Retail trade & 6.0 & 0.096 & 0.3 & 0.027 \\
\hline Ambulatory health care services & 3.6 & 0.050 & 0.5 & 0.026 \\
\hline Miscellaneous manufacturing & 0.6 & 0.011 & 2.1 & 0.023 \\
\hline Machinery & 0.8 & 0.024 & 1.1 & 0.021 \\
\hline Air transportation & 0.4 & 0.011 & 1.9 & 0.020 \\
\hline Information and data processing services & 0.6 & 0.009 & 1.8 & 0.019 \\
\hline Food services and drinking places & 2.1 & 0.037 & 0.5 & 0.017 \\
\hline Petroleum and coal products & 0.7 & 0.030 & 0.9 & 0.015 \\
\hline Federal & 4.4 & 0.068 & 0.2 & 0.015 \\
\hline Chemical products & 1.7 & 0.044 & 0.3 & 0.013 \\
\hline Motor vehicles, bodies and trailers, and parts & 0.2 & 0.039 & 0.2 & 0.012 \\
\hline Electrical equipment, appliances, and components & 0.4 & 0.010 & 0.8 & 0.010 \\
\hline Truck transportation & 0.8 & 0.019 & 0.5 & 0.010 \\
\hline Apparel and leather and allied products & 0.1 & 0.004 & 3.9 & 0.009 \\
\hline Other transportation and support activities & 0.7 & 0.010 & 0.8 & 0.008 \\
\hline Printing and related support activities & 0.2 & 0.009 & 0.9 & 0.008 \\
\hline Funds, trusts, and other financial vehicles & 0.2 & 0.008 & 1.1 & 0.008 \\
\hline Social assistance & 0.6 & 0.009 & 0.8 & 0.008 \\
\hline Wood products & 0.1 & 0.008 & 1.0 & 0.007 \\
\hline Food and beverage and tobacco products & 1.6 & 0.054 & 0.1 & 0.006 \\
\hline Textile mills and textile product mills & 0.1 & 0.006 & 1.2 & 0.006 \\
\hline Water transportation & 0.1 & 0.003 & 2.3 & 0.005 \\
\hline Plastics and rubber products & 0.5 & 0.015 & 0.3 & 0.004 \\
\hline Waste management and remediation services & 0.3 & 0.005 & 0.7 & 0.004 \\
\hline Motion picture and sound recording industries & 0.4 & 0.007 & 0.4 & 0.003 \\
\hline Furniture and related products & 0.2 & 0.006 & 0.7 & 0.003 \\
\hline Rail transportation & 0.2 & 0.005 & 0.6 & 0.003 \\
\hline Pipeline transportation & 0.1 & 0.002 & 0.7 & 0.003 \\
\hline Publishing industries (includes software) & 1.0 & 0.023 & 0.2 & 0.002 \\
\hline Forestry, fishing, and related activities & 0.2 & 0.004 & 0.2 & 0.002 \\
\hline Performing arts, spectator sports, museums, and re & 0.5 & 0.008 & 0.3 & 0.002 \\
\hline Warehousing and storage & 0.3 & 0.004 & 0.3 & 0.001 \\
\hline Support activities for mining & 0.3 & 0.006 & 1.7 & 0.001 \\
\hline Miscellaneous professional, scientific, and technica & 4.7 & 0.066 & 0.0 & 0.000 \\
\hline Paper products & 0.4 & 0.014 & 0.0 & 0.000 \\
\hline Accommodation & 0.7 & 0.015 & 0.1 & 0.000 \\
\hline Other transportation equipment & 0.6 & 0.017 & 0.0 & -0.001 \\
\hline Transit and ground passenger transportation & 0.2 & 0.002 & -0.4 & -0.001 \\
\hline Fabricated metal products & 0.8 & 0.023 & 0.0 & -0.001 \\
\hline Primary metals & 0.3 & 0.016 & 0.0 & -0.002 \\
\hline Amusements, gambling, and recreation industries & 0.4 & 0.007 & -0.5 & -0.004 \\
\hline Hospitals and nursing and residential care facilities & 3.3 & 0.049 & -0.1 & -0.005 \\
\hline Mining, except oil and gas & 0.3 & 0.005 & -0.9 & -0.006 \\
\hline Nonmetallic mineral products & 0.2 & 0.009 & -0.7 & -0.007 \\
\hline Utilities & 1.9 & 0.031 & -0.2 & -0.010 \\
\hline Insurance carriers and related activities & 2.7 & 0.045 & -0.3 & -0.012 \\
\hline Educational services & 1.1 & 0.015 & -1.2 & -0.018 \\
\hline Rental and leasing services and lessors of intangible & 1.3 & 0.020 & -1.3 & -0.026 \\
\hline Oil and gas extraction & 0.9 & 0.014 & -2.7 & -0.027 \\
\hline Legal services & 1.5 & 0.019 & -1.8 & -0.035 \\
\hline Real estate & 12.0 & 0.161 & -0.2 & -0.037 \\
\hline State and local & 9.4 & 0.138 & -0.4 & -0.055 \\
\hline Other services, except government & 2.4 & 0.042 & -1.3 & -0.056 \\
\hline Management of companies and enterprises & 1.8 & 0.026 & -2.5 & -0.067 \\
\hline Construction & 3.9 & 0.091 & -1.3 & -0.129 \\
\hline Sum & 100.0 & 1.8 & & 0.556 \\
\hline
\end{tabular}

1-Value added share is the share of industry value added to GDP

2- Domar weights are calculated as a ratio of gross output of an industry to GDP

3-Aggregate MFP growth calculated as the sum of industry percentage point contributions to aggregate MFP 
Table 6. Contributions to BLS Aggregate Multifactor Productivity Growth (percentage point)

\begin{tabular}{|c|c|c|c|c|}
\hline Description & $1998-2000$ & $2000-2007$ & 2007-2010 & 1998-2010 \\
\hline Farms & 0.11 & 0.02 & 0.14 & 0.06 \\
\hline Oil and Gas Extraction & -0.13 & -0.02 & -0.03 & -0.04 \\
\hline Support Activities for Mining & 0.05 & -0.01 & 0.01 & 0.00 \\
\hline Utilities & -0.22 & 0.10 & 0.08 & 0.04 \\
\hline Construction & -0.02 & -0.25 & 0.07 & -0.13 \\
\hline Food and Beverage and Tobacco Products & -0.01 & 0.04 & -0.05 & 0.01 \\
\hline Wood Products & 0.02 & 0.01 & -0.02 & 0.00 \\
\hline Paper Products & 0.00 & 0.01 & 0.00 & 0.01 \\
\hline Printing and Related Support Activities & -0.04 & -0.03 & 0.18 & 0.02 \\
\hline Petroleum and Coal Products & 0.05 & 0.10 & -0.05 & 0.05 \\
\hline Chemical Products & 0.02 & 0.01 & 0.02 & 0.01 \\
\hline Plastics and Rubber Products & 0.01 & 0.01 & 0.02 & 0.01 \\
\hline Computer and Electronic Products & 0.81 & 0.35 & 0.34 & 0.43 \\
\hline Electrical Equipment, Appliances, and Components & 0.05 & 0.02 & -0.01 & 0.02 \\
\hline Other Transportation Equipment & 0.02 & 0.10 & -0.01 & 0.06 \\
\hline Furniture and Related Products & 0.00 & 0.01 & -0.01 & 0.00 \\
\hline Miscellaneous Manufacturing & 0.05 & 0.03 & 0.05 & 0.04 \\
\hline Wholesale Trade & 0.19 & 0.19 & -0.12 & 0.11 \\
\hline Retail Trade & 0.02 & 0.07 & 0.18 & 0.09 \\
\hline Air Transportation & 0.07 & 0.05 & 0.02 & 0.05 \\
\hline Rail Transportation & 0.02 & 0.00 & 0.00 & 0.00 \\
\hline Water Transportation & 0.00 & 0.01 & 0.01 & 0.01 \\
\hline Truck Transportation & 0.04 & 0.02 & 0.02 & 0.02 \\
\hline Transit and Ground Passenger Transportation & 0.01 & 0.00 & 0.00 & 0.00 \\
\hline Pipeline Transportation & 0.02 & 0.00 & 0.00 & 0.01 \\
\hline Insurance Carriers and Related Activities & 0.14 & -0.02 & 0.03 & 0.02 \\
\hline Funds, Trusts, and Other Financial Vehicles & 0.02 & -0.01 & 0.00 & 0.00 \\
\hline Real Estate & 0.18 & 0.06 & -0.31 & -0.01 \\
\hline Rental and Leasing Services and Lessors of Intangible Assets & -0.18 & -0.02 & 0.06 & -0.03 \\
\hline Legal Services & 0.03 & 0.00 & -0.02 & 0.00 \\
\hline Computer Systems Design and Related Services & -0.02 & 0.06 & 0.08 & 0.05 \\
\hline Miscellaneous Professional, Scientific, and Technical Services & -0.07 & 0.04 & 0.22 & 0.07 \\
\hline Management of Companies and Enterprises & 0.02 & -0.04 & -0.10 & -0.05 \\
\hline Administrative and Support Services & 0.01 & 0.07 & 0.04 & 0.05 \\
\hline Waste Management and Remediation Services & 0.01 & 0.00 & 0.00 & 0.00 \\
\hline Educational Services & 0.01 & -0.01 & 0.00 & 0.00 \\
\hline Ambulatory Health Care Services & 0.07 & 0.02 & 0.05 & 0.03 \\
\hline Hospitals and Nursing and Residential Care Facilities & 0.00 & -0.01 & 0.03 & 0.00 \\
\hline Social Assistance & 0.00 & 0.01 & 0.01 & 0.01 \\
\hline Performing Arts, Spectator Sports, Museums, and Related Activities & 0.02 & 0.00 & 0.01 & 0.00 \\
\hline Amusements, Gambling, and Recreation Industries & 0.01 & 0.00 & -0.01 & 0.00 \\
\hline Accommodation & 0.03 & -0.01 & -0.03 & -0.01 \\
\hline Food Services and Drinking Places & 0.05 & 0.03 & -0.01 & 0.02 \\
\hline Other Services, except Government & 0.04 & -0.05 & -0.04 & -0.03 \\
\hline TOTAL NMF CONTRIBUTIONS & 0.59 & 0.72 & 0.63 & 0.68 \\
\hline TOTAL MFG CONTRIBUTION & 0.93 & 0.72 & 0.49 & 0.70 \\
\hline PRIVATE BUSINESS MFP & 1.79 & 1.44 & 0.45 & 1.25 \\
\hline
\end{tabular}


Table 7. BLS Multifactor Productivity Growth (percent growth-BLS data)

\begin{tabular}{|c|c|c|c|c|}
\hline Description & $\begin{array}{r}1998 \\
-2000\end{array}$ & $\begin{array}{r}2000 \\
-2007\end{array}$ & $\begin{array}{c}2007 \\
-2010\end{array}$ & $\begin{array}{r}1998 \\
-2010\end{array}$ \\
\hline Farms & 4.1 & 0.7 & 5.1 & 2.4 \\
\hline Forestry, Fishing, and Related Activities & 1.6 & 2.6 & -6.0 & 0.2 \\
\hline Oil and Gas Extraction & -9.3 & -0.6 & -0.2 & -2.0 \\
\hline Mining, except Oil and Gas & 1.3 & -2.5 & -0.5 & -1.3 \\
\hline Support Activities for Mining & 14.3 & -1.2 & 1.1 & 1.8 \\
\hline Utilities & -6.2 & 2.9 & 2.3 & 1.2 \\
\hline Construction & -0.2 & -2.0 & 0.7 & -1.0 \\
\hline Food and Beverage and Tobacco Products & -0.1 & 0.7 & -0.8 & 0.2 \\
\hline Textile Mills and Textile Product Mills & 0.9 & 1.6 & -1.7 & 0.7 \\
\hline Apparel and Leather and Applied Products & 2.6 & 4.2 & 2.6 & 3.6 \\
\hline Wood Products & 0.8 & 1.0 & 3.6 & 1.6 \\
\hline Paper Products & 0.7 & 0.7 & -1.2 & 0.3 \\
\hline Printing and Related Support Activities & 0.1 & 1.3 & 0.0 & 0.8 \\
\hline Petroleum and Coal Products & -2.8 & 0.4 & 2.3 & 0.3 \\
\hline Chemical Products & 1.0 & 1.9 & -0.9 & 1.0 \\
\hline Plastics and Rubber Products & 0.7 & 0.6 & 1.5 & 0.8 \\
\hline Nonmetallic Mineral Products & -1.7 & -0.7 & -0.1 & -0.7 \\
\hline Primary Metals & 1.9 & -0.4 & 1.7 & 0.5 \\
\hline Fabricated Metal Products & 0.6 & 0.6 & 0.1 & 0.5 \\
\hline Machinery & -1.4 & 1.6 & 2.9 & 1.4 \\
\hline Computer and Electronic Products & 14.1 & 9.9 & 11.7 & 11.0 \\
\hline Electrical Equipment, Appliances, and Components & 3.6 & 1.4 & -1.6 & 1.0 \\
\hline Transportation Equipment & 0.3 & 1.7 & -0.9 & 0.8 \\
\hline Furniture and Related Products & 0.4 & 1.1 & -0.9 & 0.5 \\
\hline Miscellaneous Manufacturing & 3.2 & 2.0 & 4.1 & 2.7 \\
\hline Wholesale Trade & 2.0 & 2.1 & -1.4 & 1.2 \\
\hline Retail Trade & 0.2 & 0.6 & 1.6 & 0.8 \\
\hline Air Transportation & 5.4 & 5.3 & 1.8 & 4.5 \\
\hline Rail Transportation & 3.4 & 0.4 & -0.2 & 0.7 \\
\hline Water Transportation & -0.7 & 3.4 & 2.0 & 2.4 \\
\hline Truck Transportation & 1.7 & 0.6 & 0.6 & 0.8 \\
\hline Transit and Ground Passenger Transportation & 3.3 & -0.2 & -1.1 & 0.1 \\
\hline Pipeline Transportation & 7.2 & 0.2 & -1.9 & 0.8 \\
\hline Other Transportation and Support Activities & 0.8 & 2.0 & -1.6 & 0.9 \\
\hline Warehousing and Storage & -1.8 & 0.6 & 1.0 & 0.3 \\
\hline Publishing Industries & -4.1 & 2.4 & -0.4 & 0.6 \\
\hline Motion Picture and Sounds Recording Industries & -7.5 & 3.7 & -1.7 & 0.4 \\
\hline Broadcasting and Telecommunications & 0.4 & 3.3 & 0.5 & 2.1 \\
\hline Information and Data Processing Services & -15.3 & 5.6 & 1.1 & 0.7 \\
\hline Federal Reserve Banks, Credit Intermediation, and Related Activities & 1.6 & 0.0 & 3.3 & 1.1 \\
\hline Securities, Commodity Contracts, and Investments & 8.6 & 2.0 & 2.5 & 3.2 \\
\hline Insurance Carriers and Related Activities & 4.7 & -1.0 & 1.1 & 0.5 \\
\hline Funds, Trusts, and Other Financial Vehicles & 1.3 & -0.7 & -1.2 & -0.5 \\
\hline Real Estate & 2.1 & 0.6 & -3.6 & -0.2 \\
\hline Rental and Leasing Services and Lessors of Intangible Assets & -7.0 & -1.0 & 2.4 & -1.2 \\
\hline Legal Services & 1.3 & -0.1 & -1.0 & -0.1 \\
\hline Computer Systems Design and Related Services & -1.1 & 3.1 & 3.3 & 2.4 \\
\hline Miscellaneous Professional, Scientific, and Technical Services & -0.9 & 0.5 & 2.4 & 0.7 \\
\hline Management of Companies and Enterprises & 0.6 & -1.1 & -2.5 & -1.2 \\
\hline Administrative and Support Services & 0.1 & 1.3 & 0.9 & 1.0 \\
\hline Waste Management and Remediation Services & 1.4 & 0.7 & 0.5 & 0.7 \\
\hline Educational Services & 0.9 & -0.8 & 0.1 & -0.3 \\
\hline Ambulatory Health Care Services & 1.2 & 0.3 & 0.8 & 0.6 \\
\hline Hospitals and Nursing and Residential Care Facilities & -0.1 & -0.3 & 0.7 & 0.0 \\
\hline Social Assistance & 0.0 & 1.4 & 1.0 & 1.1 \\
\hline Performing Arts, Spectator Sports, Museums, and Related Activities & 3.1 & 0.1 & 0.5 & 0.7 \\
\hline Amusements, Gambling, and Recreation Industries & 1.3 & -0.5 & -0.8 & -0.3 \\
\hline Accommodation & 1.7 & -0.7 & -1.7 & -0.5 \\
\hline Food Services and Drinking Places & 1.5 & 0.8 & -0.2 & 0.6 \\
\hline Other Services, except Government & 0.8 & -1.0 & -1.0 & -0.7 \\
\hline
\end{tabular}

